\title{
An evaluation of the impact of the Dublin Port Tunnel and HGV management strategy on air pollution emissions
}

Jiayi Tang ${ }^{a *}$, Aonghus McNabola ${ }^{a}$, Bruce Misstear ${ }^{a}$, Brian Caulfield ${ }^{a}$

${ }^{a}$ Civil, Structural and Environmental Engineering Department, Trinity College Dublin, College Green, Dublin 2, Ireland

*Corresponding author

\section{Highlights}

- The impacts of changes in transport infrastructure and HGV management strategies on traffic emissions were assessed.

- The HGV management strategy improved speed distributions.

- Both of these changes resulted in vehicles travelling for longer distances on average.

- Both of these changes made the total air pollutant emissions increase.

\section{Keywords}

Traffic model; emissions; Dublin Port Tunnel; air pollution; transport impacts on environment

\begin{abstract}
Heavy Goods Vehicles (HGVs) contribute a large proportion (about 40\%) of the emissions of air pollutants while only representing a small proportion (about 10\%) of all transport operations. In Ireland, the Dublin Port Tunnel (DPT) was opened in 2006 as a dedicated route for HGVs between Dublin Port and the motorway system in order to reduce the HGV volume in the city centre. An HGV management strategy to restrict HGVs travelling through the city centre was also introduced. The aim of this study was to estimate the emission changes brought about by these infrastructural and regulatory changes. A transport model built in VISUM was utilised. Emissions were calculated using COPERT 4. The results showed that the DPT and HGV management strategy reduced the traffic in the city centre, and the HGV management improved traffic speed distribution. However the DPT and HGV management resulted in vehicles travelling further (travel distance increased by $16 \%$ and $51 \%$, respectively) and increased the total emissions (increased by $8 \%$ and $21 \%$ in $\mathrm{NO}_{\mathrm{x}}$, respectively). Total traffic and emission changes over time in Dublin were also estimated in this study. The traffic conditions and emissions in 2006, 2007 and 2013 were evaluated and the results indicated that a travel demand reduction in 2013 could also improve speed distribution. Emissions reduced from 2006 to 2013 and the fleet technology improvements had a positive impact on this reduction. The study shows that a traffic management policy and/or infrastructure change may bring about some localised environmental benefits within the management area; however, such a policy does not always reduce the total traffic emissions in the network as a whole and the impact to the wider environment could be negative in some circumstances.
\end{abstract}

* Corresponding author. Tel: +353 18962045.

E-mail addresses: jitang@tcd.ie (Jiayi Tang), amcnabol@tcd.ie (Aonghus McNabola), bmisster@tcd.ie (Bruce Misstear), Brian.Caulfield@tcd.ie (Brian Caufield). 


\section{Introduction}

Traffic is one of the major users of energy and one of the major polluting sectors. It is considered a significant cause of the monitored exceedances of ambient air quality limit values in urban areas (EEA, 2013a). In 2011, the contribution of road transport emissions to nitrogen oxide $\left(N O_{x}\right)$ and carbon monoxide (CO) in Europe amounted to $40 \%$ and $26 \%$, respectively (EEA, 2013b). Traffic is also a major source of particle emissions ( $\mathrm{PM}_{10}$ and $\left.\mathrm{PM}_{2.5}\right)$ (Pant and Harrison, 2013).

Compared to industrial and other air pollution causes, air pollution from road transport is more likely to affect people, because the source of air pollution from transport, i.e. vehicles are often within close proximity to residential and workplace locations, in addition to exposure during commuting. Among all traffic modes, Heavy Goods Vehicles (HGVs) are a significant contributor to traffic pollution. An OECD report highlights that trucks can produce over 40 percent of the pollution where they only account for 10 percent of all transport operations in urban areas (OECD, 2003).

Governments all over the world are taking actions to reduce traffic emissions and to build a sustainable urban transport system. Some commonly considered options in cities for these purposes include: road infrastructure, public transport, technological solutions, vehicle access restrictions and control of land-uses (Pojani \& Stead, 2015).

In cities, regulations aimed at restricting vehicle access have had an important impact on traffic emissions and air quality. In London, a low emission zone (LEZ) was implemented in 2008, which restricted some vehicles entering the zone. Ellison et al. (2013) concluded that the LEZ may have reduced $\mathrm{PM}_{10}$ emissions by $2.47-3.07 \%$ within the zone whereas by only $1 \%$ outside the zone. In Munich, after the implementation of a LEZ, PM 10 concentrations in the LEZ were found to be reduced by 5-12\% at almost all the monitoring sites (Cyrys et al., 2009). In China, some cities have implemented a license plate restriction policy, which prohibit a portion of cars entering the restriction zone at a particular time. Pu et al. (2015) found that in the license plate restriction zone in Hangzhou city in China, emissions decreased by $6.9 \%$.

Transport infrastructure changes influence emissions and air quality as well as influencing traffic flows. Lozano et al. (2014) found a new toll highway had positive effects on emissions in the short term in Mexico City. Bandeira et al. (2013) estimated the emissions impact of vehicles choosing different routes. They found that faster intercity routes tended to reduce fuel use and $\mathrm{CO}_{2}$ emissions, however they increased emissions of carbon monoxide, nitrous oxides, and hydrocarbons by up to $150 \%$ (Bandeira et al., 2013).

Focusing on Ireland, the national government proposed a set of strategies to reduce transport air pollution and $\mathrm{CO}_{2}$ emission, including: regulating vehicle standards, implementing compulsory measures to restrict large vehicles, encouraging people to shift transport mode, and launching large infrastructural projects (Department of the Environment Heritage and Local Government, 2007).

In Dublin city, strategies taken that have had impacts on traffic emissions include improved infrastructure and vehicle restriction access: the Dublin port tunnel (DPT) was opened on December $20^{\text {th }} 2006$ as a dedicated route for HGVs between Dublin Port and the national road network to remove trucks from the city centre. A HGV management strategy was introduced on the $19^{\text {th }}$ of February 2007 in Dublin. This strategy implemented a ban on 5+ axle HGVs prohibiting them from entering the city cordon area (roads that within the cordon area are shown in Figure 1 in red). It 
aimed to encourage maximum use of the Port Tunnel by port related traffic and thus to minimize the numbers of trucks on the city streets. This would in turn enhance the city centre environment through reduced congestion, noise and air pollution (O'Brien and Bolger, 2009).

Significant changes in traffic and air quality have been observed after the opening of the DPT and the implementation of the HGV management strategy. Decreases in 5+ axle vehicles of between $33 \%$ $90 \%$ were recorded in the city centre. There were also reductions of 3 axle and 4 axle vehicles (Finnegan et al., 2007). Three years after the operation of the HGV Management Strategy dramatic reductions of $5+$ axle vehicles were also observed within the city centre, between $88-96 \%$ and over 3,582 5+ axle vehicles used the tunnel per day in 2009 (O'Brien and Bolger, 2009). An environmental assessment unit installed in the city centre witnessed a $26 \%$ drop in average daily $\mathrm{PM}_{10}$ concentration after the opening of the DPT, from $35.5 \mathrm{ug} / \mathrm{m}^{3}$ to $26.2 \mathrm{ug} / \mathrm{m}^{3}$. It also recorded a $36 \%$ decrease in average daily $\mathrm{PM}_{10}$ concentration after the introduction of the HGV management strategy, from $35.5 \mathrm{ug} / \mathrm{m}^{3}$ to $22.7 \mathrm{ug} / \mathrm{m}^{3}$ (Finnegan et al., 2007). However, this monitoring site only recorded $\mathrm{PM}_{10}$ concentrations over a short period at a fixed location within the city centre. The full impact of this infrastructure and regulatory change on air quality and emissions in the city of Dublin as a whole is not fully understood. Since a significant traffic change has been witnessed after the opening of DPT and the implementation of the HGV management strategy, a holistic evaluation of the emission change brought by this traffic change is needed to improve our understanding of the impacts of infrastructure and regulatory changes on air quality.

The DPT and HGV strategy had significant impacts on vehicle route choices and traffic conditions, as the DPT provided an extra route and the HGV strategy restricted some other routes. As one of the design functions of the DPT and the HGV strategy was to improve the environment of the city centre, it is important to know how these perform regarding reducing emissions.

In this paper an evaluation of the impacts of changes in transport infrastructure and policy on air pollution emissions was conducted. The evaluation focused on the role of HGV transport in the urban environment and highlights methods to improve environmental impact and adjust existing policy. Macroscopic traffic models and emission models were used to evaluate the impact of the DPT and a proposed new HGV management strategy on total emissions in the Dublin city region. Since its inception the HGV strategy has brought about changes in traffic and air quality, and it has been proposed that the strategy would be extended to include all types of HGVs (Finnegan et al., 2007). The current study estimated the impact of such a scenario where all HGVs are prohibited from entering the city centre. This study also examined the traffic and emission changes over time in order to evaluate the impact of different travel demands and the effect of vehicle technology improvements alongside infrastructure and regulatory changes. The paper aims to develop appropriate policy suggestions regarding reducing traffic congestion and emissions through the evaluation of these impacts.

\section{Methodology and Data}

The traffic change brought about by the DPT and a proposed HGV management strategy was simulated using a traffic model built in VISUM (PTV company, 2014). The emission change brought 
about by this traffic change was then estimated using COPERT 4 (Leon and Zissis, 2014). The data requirements and sources for the traffic and emission models are summarized below:

1. Road network information was derived from the map in VISUM and the National Transport Model (NTpM) of Ireland (NRA, 2014, PTV company, 2014);

2. Origin-Destination matrices were extracted from the National Traffic Model (NTM) of Ireland and NTpM (NRA, 2014);

3. Traffic count records were obtained from Dublin City Council (DCC);

4. Fleet composition data were obtained from the Environmental Protection Agency of Ireland (Ireland EPA, 2015).

The NTpM has been constructed and updated in 2011 and 2013 respectively by Irish National Roads Authority (NRA, 2014). However, NTpM being an all-Ireland multi-modal transport model was calibrated and validated at a strategic level and therefore the model required recalibration in order to reflect accurately the situation at the regional level in Dublin city.

\subsection{Traffic model}

In order to simulate the traffic change brought about by the DPT and a proposed HGV management strategy, and also to investigate the effects of traffic and emission changes over the time, five scenarios in the Dublin area were included in this paper. Four scenarios were based on real conditions and one scenario was hypothetical. These scenarios were simulated by the traffic model and were compared with each other, as shown on Table 1 below:

\begin{tabular}{|c|c|c|}
\hline No. & Scenario & Description \\
\hline 1 & 2006 no DPT & One average hour traffic from 7 to 9am from 1/1/2006 to 20/12/2006 \\
\hline 2 & 2006 DPT & One average hour traffic from 7 to 9am from 21/12/2006 to 19/02/2006 \\
\hline 3 & 2006 DPT+Ban & Hypothetical scenario \\
\hline 4 & 2007 DPT+Ban & One average hour traffic from 7 to 9am from 20/02/2007 to 31/12/2007 \\
\hline 5 & 2013 DPT+Ban & One average hour traffic from 7 to 9am across 2013 \\
\hline
\end{tabular}

Table 1. Times and dates represented by 5 scenarios. DPT+Ban represents DPT\&HGV management scenarios.

These scenarios contained the following conditions: 1) before the tunnel was opened, i.e. 2006 no DPT; 2) after the tunnel was opened but before the HGV strategy was implemented, i.e. 2006 DPT; 3) after the HGV strategy was implemented, i.e. 2006 DPT+Ban, a hypothetical scenario; and 4) and 5) the 2007 and 2013 DPT+Ban scenarios. The traffic model simulated one average hour from the period of the AM peak (7:00-9:00am). Scenarios in the years 2006, 2007 and 2013 utilized the traffic data of the year 2006, 2007 and 2013 respectively. The traffic model consisted of a network model based in VISUM, a demand model and various impact models.

\subsubsection{The network model}

Figure 1 below displays the network model built in VISUM representing the nodes, zones and links in Dublin city. The links in the network included the main roads in Dublin, i.e. motorways, national roads, regional roads and some local roads. As small roads and alleys had limited capacity for allocating trips, and thus little impact on the final results, these were excluded. 764 links were included in this study. 
Travel information was recorded according to electoral divisions (EDs) from census data in Ireland. The Dublin area was divided into 30 zones according to EDs or amalgamations of EDs. The model also included internal zones covering the modelled area and external zones representing travel between the modelled area and the rest of Ireland.

For the scenarios before the DPT was opened, the network models did not have the link of the DPT. For the scenarios after the HGV strategy was implemented, a proposed HGV management strategy was used to evaluate the impact of a full HGV ban on the city centre. This prohibited HGVs entering the cordon area in the city centre. Links within the cordon area were blocked for HGVs in the network models, as shows in Figure 1.

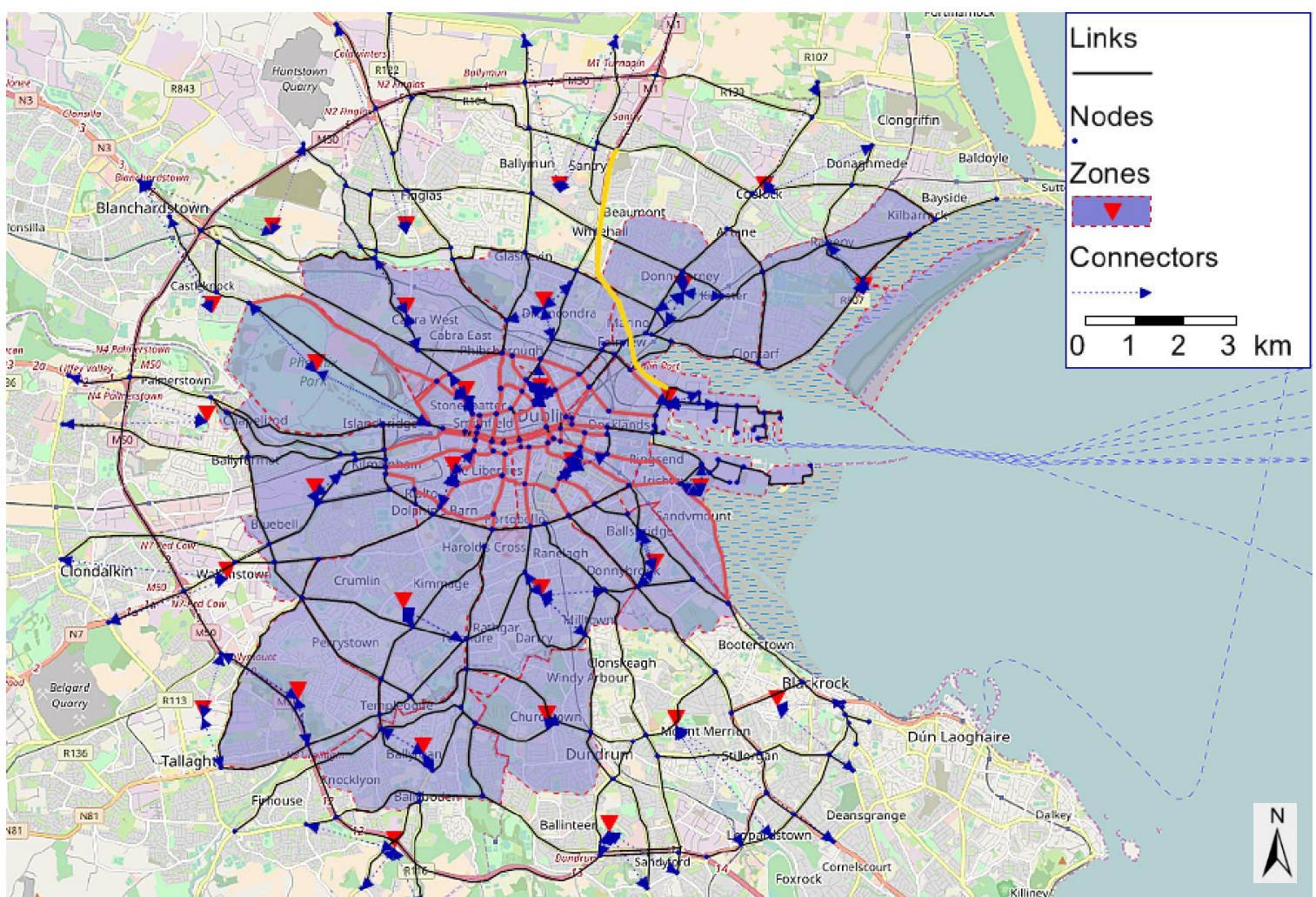

Fig. 1. The VISUM network and prohibited links for HGVs within cordon area (red links). The Yellow link represents the location of the DPT.

\subsubsection{The demand model}

The demand model contained the travel demand data in the form of trip matrices information for cars and HGVs, derived from NTM and NTpM. For 2006 scenarios, the trip matrices, i.e. Origindestination (OD) matrices information for the year 2006 were used and calibrated with the traffic count data of 2006. For the scenario 2007 DPT+Ban, trip matrices for 2006 were used and calibrated according to the traffic count data of 2007. For the 2013 DPT+Ban scenario, trip matrices for the year 2013 was used and calibrated with the traffic count data of 2013.

The trip matrices for cars and HGVs in 2006 were extracted from NTM. NTM is a strategic traffic model of Ireland's national road network. The data used for travel matrix development for light vehicles and heavy vehicles of NTM were observed trip data obtained from road side interviews (RSI). It also made use of information contained in an Irish census of 2006 Place of Work - Census of 
Anonymous Records (POWCAR). NTM modelled an average hour in the morning peak between 07:00 and 09:00 (AM hour) for the base year 2006 (NRA, 2009).

A modified version of the NTM was used during this study. It was downscaled to 30 zones according to the zones of the study area. The zones outside the Dublin city in the NTM model were aggregated and regarded as an external zone representing the travel between the Dublin city and the rest of Ireland.

The trip information for 2013 was obtained from NTpM which was established in 2011 and updated in 2013. NTpM is the successor of the NTM. The demand of NTpM for travel by car and HGVs was constructed based on data from the: 2011 POWCAR survey (CSO, 2011); 267 NRA Traffic Monitoring Units; Surveys and information from the previous version of the NTM; National Survey of Transport of Goods by Road by CSO; and various traffic survey data collected by the NRA in 2013 (NRA, 2014).

An extracted model of NTpM was also downscaled to 30 zones according to the zones of the study area. The zones outside Dublin city in the extracted NTpM model were amalgamated and regarded as external zones representing the travel between the Dublin city and the rest of Ireland.

After trips of cars and HGVs were assigned to roads, trip matrices were calibrated to adjust the assigned volume to real traffic counts. Because the NTM and NTpM are national models which reflect the trips at a national level rather than a local level, re-calibration against traffic count data within Dublin city was conducted.

\subsubsection{Calibration}

The data for calibrating the demand model was obtained from Dublin City Council and the National Roads Authority. The TFlowFuzzy technique was used to calibrate OD matrices (PTV company, 2014). The calibration process was designed to automatically manipulate the OD matrices to match a counted volume along a particular link or multiple links, making the difference between the assignment volume and the actual volume less than a tolerance.

As this study simulated situations for one average hour from the period of the AM peak, the traffic count data being used was correspondingly the traffic volume of one average AM hour for the year. As mentioned in Section 2.1, scenarios in the years 2006, 2007 and 2013 utilized the traffic counts data of the corresponding year. As the scenario of 2006 DPT existed for a very short time (about 11 days in the end of 2006), the annual traffic counts for 2006 actually represents the conditions of 2006 no DPT scenario. Therefore the 2006 no DPT scenario was calibrated with 2006 traffic counts, and the 2006 DPT scenario and the hypothetical 2006 DPT+Ban scenario utilized the same OD matrices as the 2006 no DPT scenario.

The UK Design Manual for Roads and Bridges (UK DMRB, 1997) specifies the acceptable values for modelled and observed flow comparisons and suggests how calibration should be conducted in this context. These calibration criteria were observed in this study and are summarized in the supplementary materials section, Table S1. 17 links selected to calibrate the model, based on available data, as shown in Figure 2. The modelled traffic volumes were set to meet the criteria using the TFlowFuzzy approach. 


\subsubsection{Validation}

Validation used independent traffic data from that used in the calibration process. Validation criteria for tolerance implemented in this study were the same as the calibration criteria. For each link, the validation process checked whether the difference between the assignment volume and the actual volume was within the tolerance range.

Five links were selected for validation and all of these links met the validation criteria. Figure 2 also shows the links that have met the validation criteria.

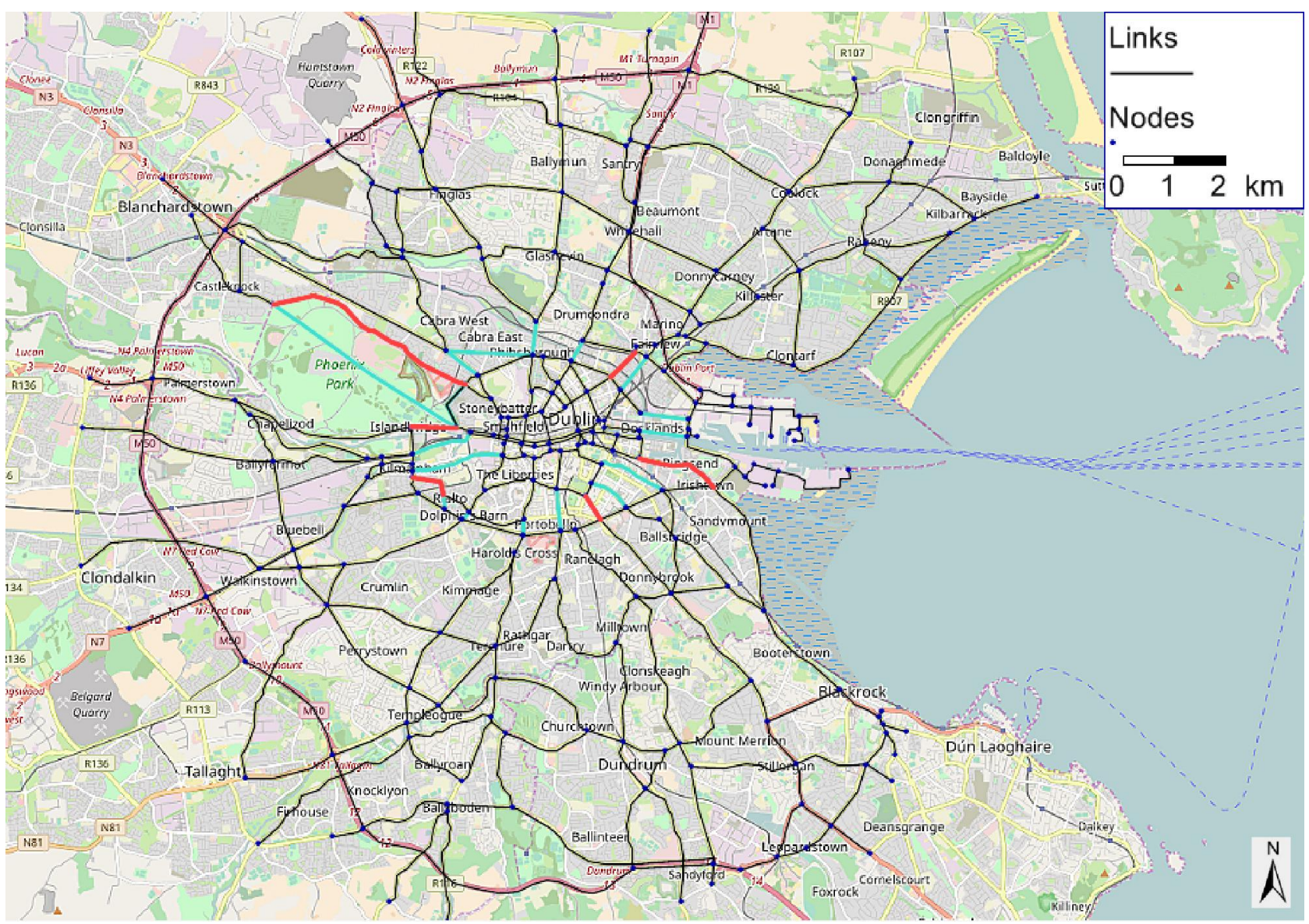

Fig. 2. Links of calibration (blue line) and links that met the validation criteria (red line).

\subsubsection{The impact model}

The impact model used input data provided by the network model and the demand model to calculate the impact of traffic in order to analyse and evaluate transport supply. The attributes of network objects such as the vehicle congested speed on each link and the length of each link, were calculated and used in the subsequent emission calculations.

\subsection{Emission model}

Emissions were estimated using COPERT 4. The emission factors were obtained from those used in the COPERT 4 emission model. COPERT has been developed for official road transport emission inventory preparation in EEA member countries. These emission factors are suitable for EU 
conditions. The COPERT methodology is part of the EMEP/EEA air pollutant emission inventory guidebook for the calculation of air pollutant emissions and is consistent with the 2006 IPCC Guidelines for the calculation of greenhouse gas emissions (Leon and Zissis, 2014). Therefore it is appropriate to use COPERT 4 to estimate emissions in Irish conditions.

Emissions can be classified into exhaust emissions and evaporative emissions for non-methane volatile organic compounds (NMVOCs). For particulate matter (PM) road vehicle tyre/brake wear and road wear caused by vehicle's motion emissions are also included (Leon and Zissis, 2014).

For exhaust emissions, these were calculated as the sum of hot emissions (when the engine is at its normal operating temperature) and emissions during transient thermal engine operation (termed 'cold-start' emissions). As the trip amount and the type of vehicles are not affected by the opening of the DPT, and the simulation hour of different scenarios are all in December and thus have a similar temperature, the effect of cold emission was not considered.

Emissions were calculated by combining activity data for each vehicle category with appropriate emission factors. These emission factors are pertinent to the technology standards available in Ireland (e.g. EURO Class 1, 2, 3, 4, 5, 6) and the classification of the Irish vehicle fleet was also conducted according to these technology standards. The emission factors also varied according to other input data (driving situations, climatic conditions).

The number of vehicles per category and class was obtained from national vehicle fleet composition data. National fleet composition of 2006, 2007 and 2013 were derived from Environmental Protection Agency of Ireland (Ireland EPA, 2015) which included the number of vehicles for every exhaust emission legislation class of each vehicle category. In this study, it was assumed that the proportion of each vehicle category and class to the total amount of vehicles within simulation area equalled the proportion of that for Ireland as a whole. More than $40 \%$ of the population of Ireland is located in the Greater Dublin Area, and Dublin as a sample of Ireland as a whole, is a quite large sample. The Irish national fleet therefore represents the fleet composition in Dublin very well. Details of the National fleet composition of 2006, 2007 and 2013 are listed in the supplementary materials section in Table S2.

Not taking evaporative and cold-start emissions into account, the formula for estimating emissions for a given time period, and using experimentally-obtained emission factors, is expressed by Equation 1:

Emission $[\mathrm{g}]=$ emission factor $[\mathrm{g} / \mathrm{km}] \times$ number of vehicles [veh] $\times$ distance per vehicle $[\mathrm{km} / \mathrm{veh}]$

Different emission factors, numbers of vehicles and distance per vehicle were present for each vehicle category and class. The emission factors depended on the vehicle class and emissions control technology the vehicle applies. Within each vehicle class, the emission factor also depended on the vehicle speed. The information for vehicle speed and distance per vehicle were derived from the traffic model.

For each vehicle class, the two items on the right side of Equation 1 of number of vehicles [veh] (in the traffic model) $\times$ distance per vehicle [ $\mathrm{km} / \mathrm{veh}$ ] (in the traffic model) represented the total distance that vehicles of this class travelled in the traffic model. In this study, because the total distance travelled by cars and HGVs respectively could be derived from the traffic model and the proportion of each vehicle class in the simulation area was assumed to be the same as the national fleet composition, these two items for each class were expressed by Equation 2 . 
Where, the total distance refers to the total distance that every vehicle travelled in the traffic model; the total number of vehicles refers to the total number of vehicles in the Irish fleet; and the number of vehicles of a class refers to the number of vehicles with the same technology in the Irish fleet.

In Equation 2, the vehicles were divided into two general types, cars and HGVs. For each type there were different categories and classes. Total distance was calculated for each type respectively.

Vehicle speed was introduced into the calculation via three average speeds and their shares, which influenced the emission factor. For cars, the speed range and average speed are displayed in Table 3 as follows:

\begin{tabular}{|c|c|c|c|}
\hline Group & 1 & 2 & 3 \\
\hline Speed range $(\mathrm{km} / \mathrm{h})$ & $5-35$ & $36-65$ & $66-95$ \\
\hline Average speed $(\mathrm{km} / \mathrm{h})$ & 20 & 50 & 80 \\
\hline
\end{tabular}

Table 3. Average speed for each speed range for cars.

For HGVs, because the speed limit on the motorway was $90 \mathrm{~km} / \mathrm{h}$ (LEO, 2012), the average speed and speed range were $78 \mathrm{~km} / \mathrm{h}$ and $66-90 \mathrm{~km} / \mathrm{h}$ respectively. The speed range and average speeds are displayed in Table 4.

\begin{tabular}{|c|c|c|c|}
\hline Group & 1 & 2 & 3 \\
\hline Speed range $(\mathrm{km} / \mathrm{h})$ & $5-35$ & $36-65$ & $66-90$ \\
\hline Average speed $(\mathrm{km} / \mathrm{h})$ & 20 & 50 & 78 \\
\hline
\end{tabular}

Table 4. Average speed for each speed range for HGVs.

The percentage distance that a vehicle driving with a speed within each speed range was given by Equation 3.

Share $=$ Distance vehicles travelled with the speed within the range of each group [km] / total distance vehicles travelled [km]

Equation 3 was applied to each vehicle category and class. Different emission factors, numbers of vehicles and distance per vehicle, for each vehicle category and class were calculated with the data and method mentioned above, for each of the five scenarios examined. Emissions of $\mathrm{CO}, \mathrm{CH}_{4}, \mathrm{NO}_{\mathrm{x}}$, $\mathrm{PM}, \mathrm{CO}_{2}$ were calculated.

\section{Results}

\subsection{Traffic simulation}

Differences in traffic between different scenarios are displayed in Figures 3 to 6 . These figures show the results of the traffic volume difference for each link between a number of the scenarios, as follows:

- scenario 2006 DPT minus 2006 (Figure 3)

- no DPT, 2006 DPT+Ban minus 2006 DPT (Figure 4)

- 2007 DPT+Ban minus 2006 DPT+Ban (Figure 5)

- 2013 DPT+Ban minus 2007 DPT+Ban (Figure 6) 
The volume differences for cars are represented by a red bar. Light red shows that the volume difference is less than 0 and dark red shows the opposite. For example in Figure 3, links with dark red bars represent the links where the traffic volumes in the scenario 2006 DPT are more than in 2006 no DPT. The width of the link bar indicates the magnitude of volume difference. The blue bar on each link represents the volume difference for HGVs. Light blue shows that volume difference is less than 0 and dark blue shows the opposite.

Figure 3 indicates that after the opening of the DPT, cars and HGVs in the city centre decreased by approximately 400-500 cars/hr and around 100-200 HGVs/hr. In the DPT, cars and HGVs increased by about 2000-2500 cars/hr and 800-900 HGVs/hr. Cars and HGVs travelled through the DPT and avoided travelling through the city centre, therefore traffic volume (veh/hr) in the city centre decreased.

Figure 4 indicates traffic changes for the hypothetical scenario 2006 DPT+Ban minus the scenario of 2006 DPT. This result allows us to see the traffic changes brought about by the HGV management implementation. It shows a decrease of the HGV volume by about 100-200 HGVs/hr within the city centre and a rise of HGV volume on the DPT and some links outside the city centre by around 200$400 \mathrm{HGVs} / \mathrm{hr}$. On the M50, a motorway that encircles Dublin, the HGV volume increased by about 200-800, demonstrating that the HGVs travelled to the motorway network through the DPT without travelling through the city centre. This shows that the HGV management changed the route travelled by HGVs but had little impact on cars.

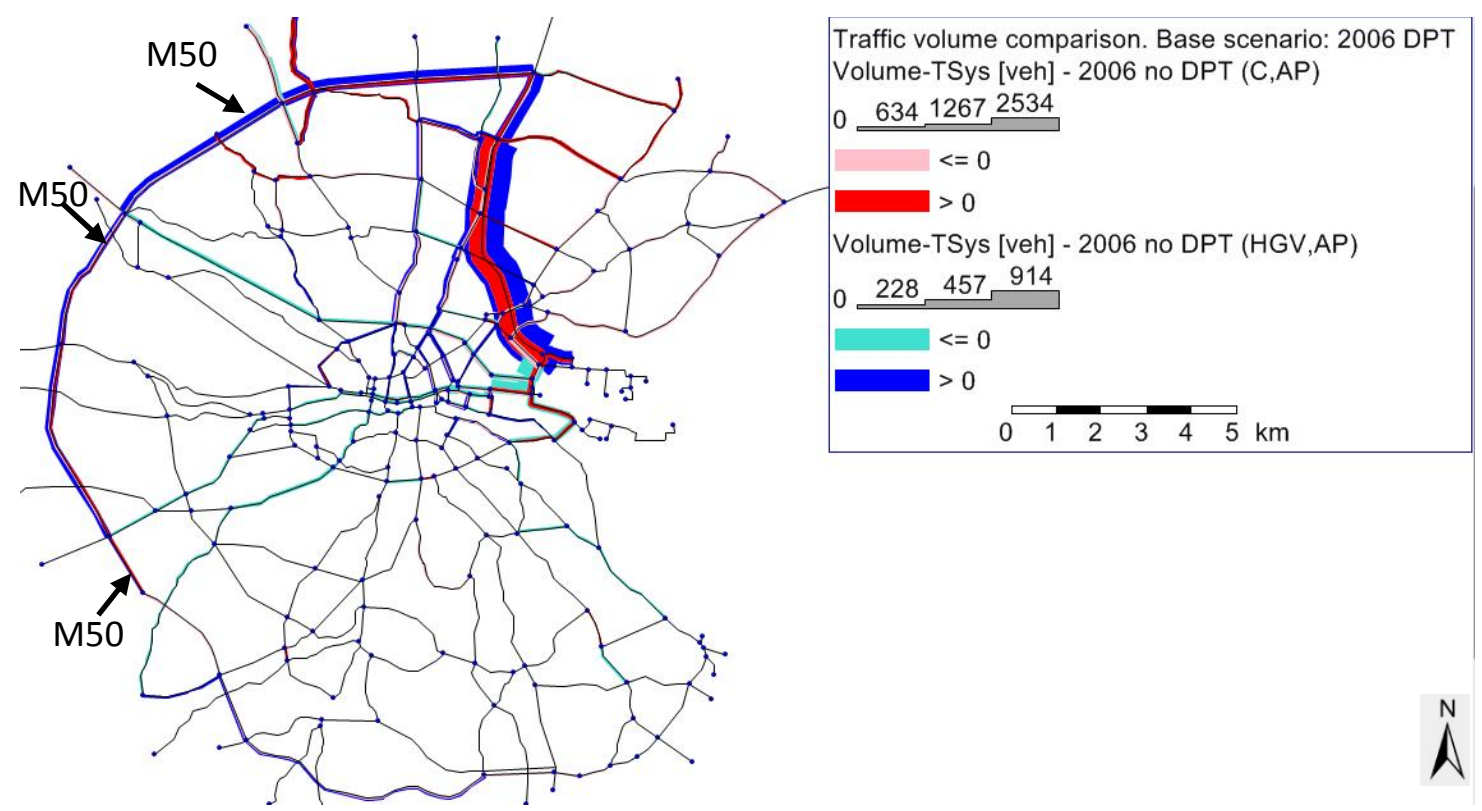

Fig. 3. Traffic volume comparison. 2006 DPT minus 2006 no DPT. 


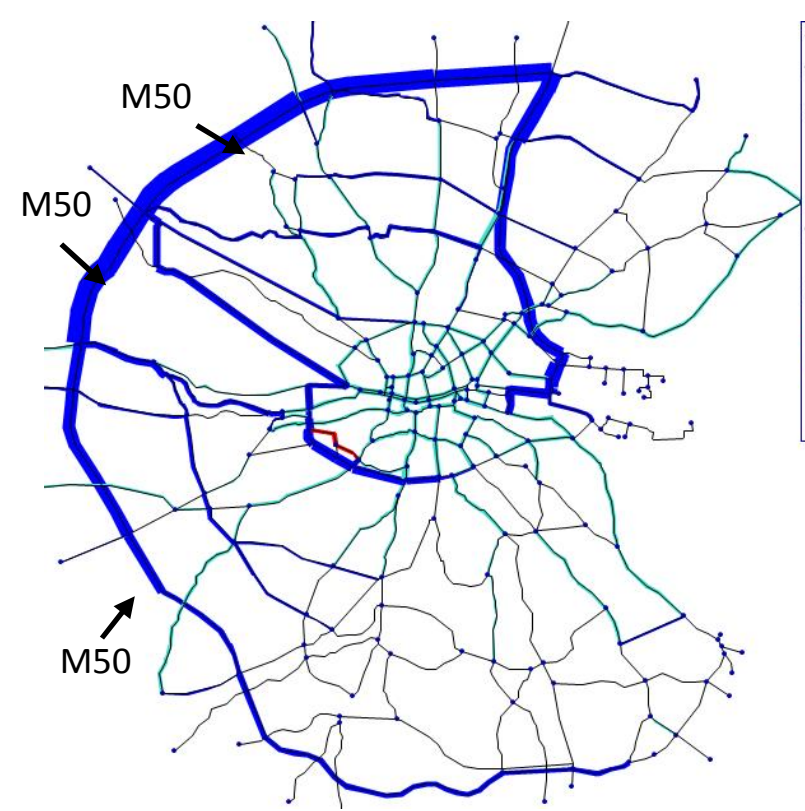

Traffic volume comparison. Base scenario: 2006 DPT+Ban Volume-TSys [veh] - 2006 DPT (C,AP)

$0 \lcm{94188 \underline{376}}$

$<=0$

Volume-TSys [veh] - 2006 DPT (HGV,AP)

$0 \lcm{190 \quad 379759}$

$<=0$

$>0$

$\begin{array}{lllllll}0 & 1 & 2 & 3 & 4 & 5 & \mathrm{~km}\end{array}$

Fig. 4. Traffic volume comparison. 2006 DPT\&HGV strategy minus 2006 DPT.

Figure 5 shows scenario 2007 DPT+Ban minus 2006 DPT+Ban. It represents the traffic difference of a real situation which took the travel demand changes between 2006 and 2007 into account. There were rises and drops for traffic volumes for different links, with changes of less than $1000 \mathrm{cars} / \mathrm{hr}$ and less than $100 \mathrm{HGVs} / \mathrm{hr}$.

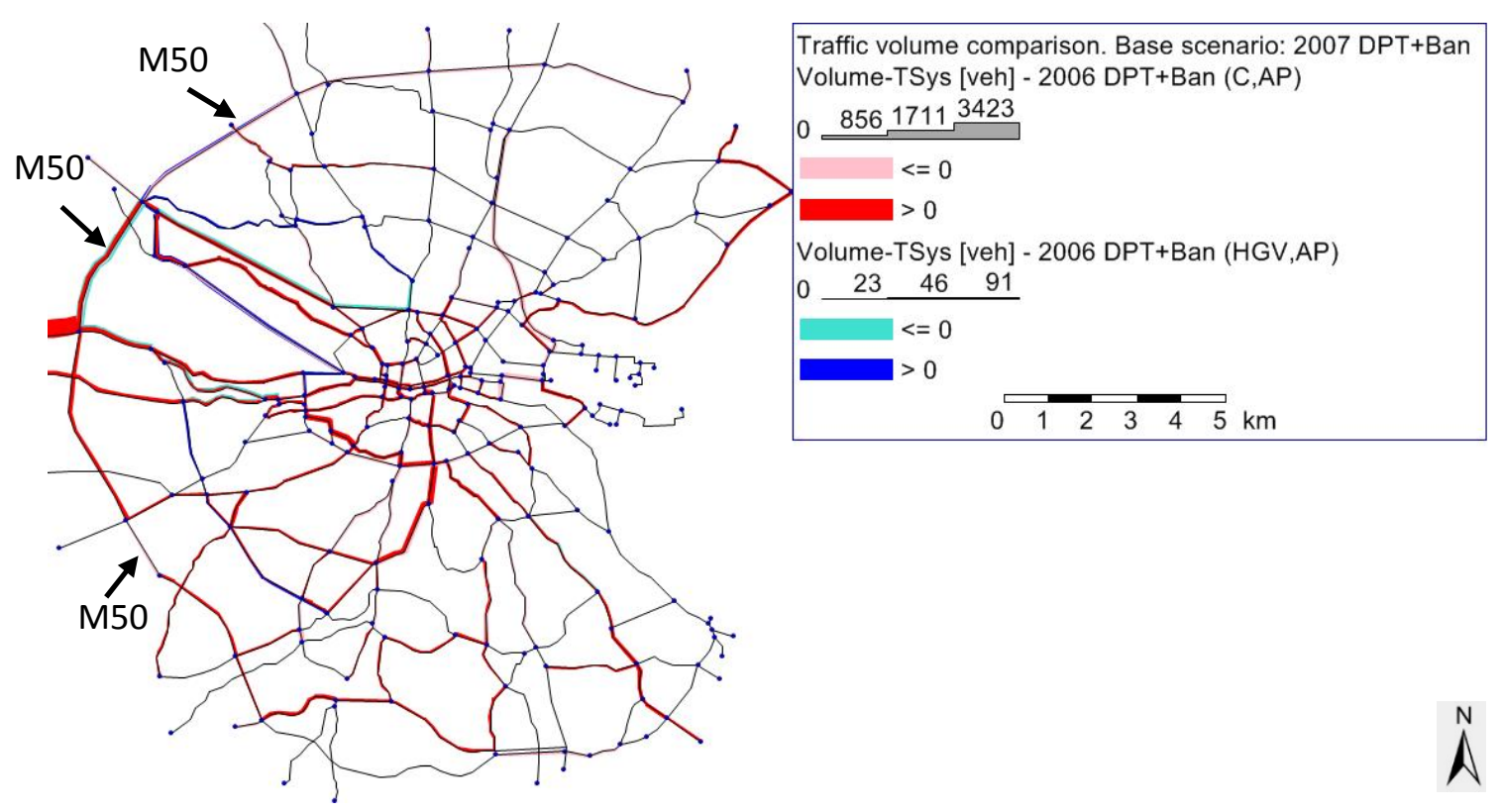

Fig. 5. Traffic volume comparison. 2007 DPT\&HGV strategy minus 2006 DPT\&HGV strategy.

Figure 6 displays traffic volumes of 2013 DPT+Ban minus 2007 DPT+Ban, illustrating the impact of the infrastructure and policy change under significantly different travel demand and vehicle fleet 
conditions. A quite obvious decrease of HGVs can be seen in the DPT and on the M50. This is due to the drop of the total HGV travel demand in 2013 which can also be seen in the Figure 7.

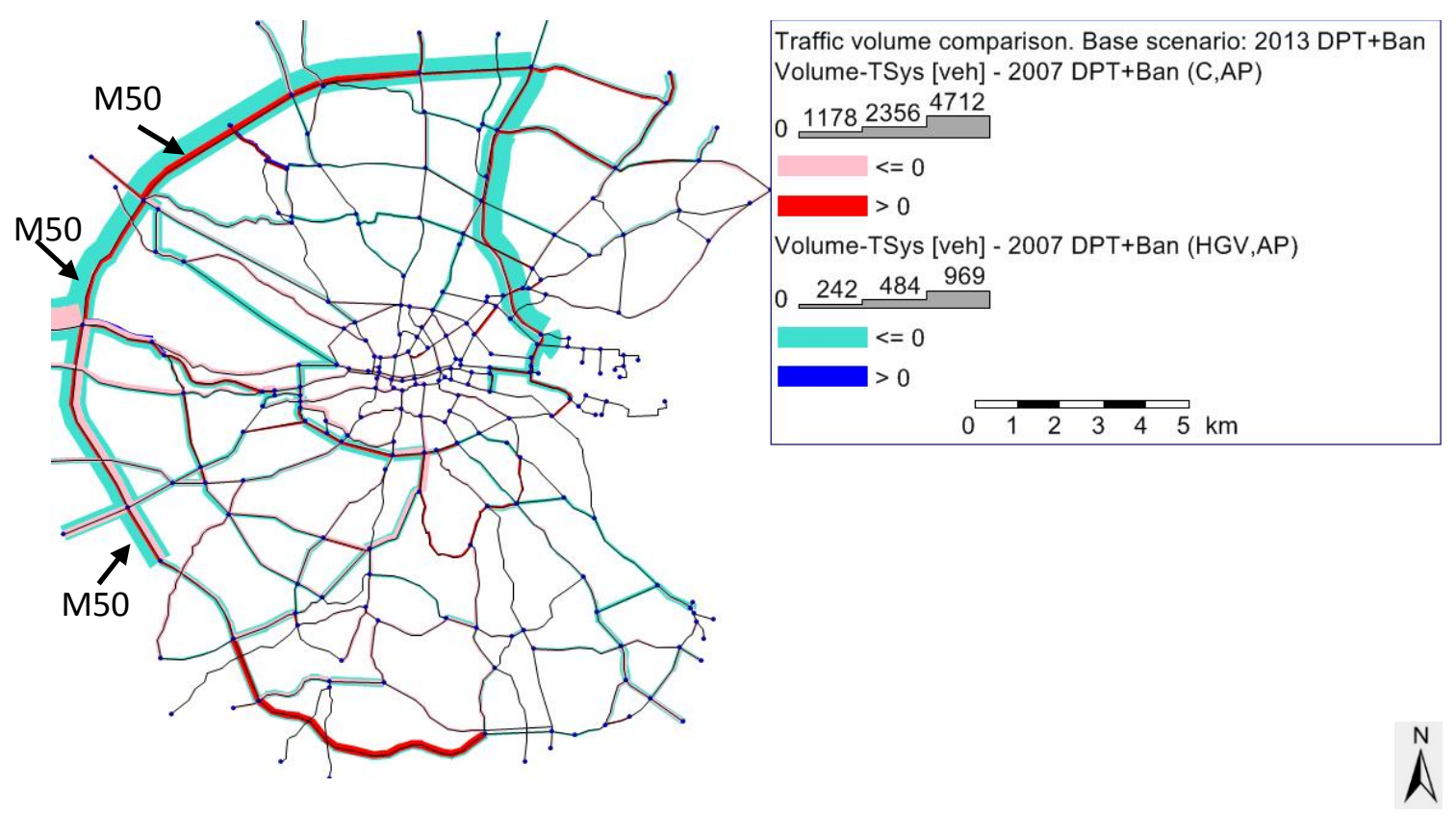

Fig. 6. Traffic volume comparison. 20013 DPT\&HGV strategy minus 2007 DPT\&HGV strategy.

Figure 7 shows the total distance travelled by every vehicle (i.e. vehicle kilometers travelled) and the direct distance for all the trips in the five different scenarios. Direct distance is referred to here as the sum of each trip multiplied by the direct distance from origin to destination of this trip. It represents the shortest distance to be travelled for a given OD matrix. Figure 8 shows the ratio of the total distance to the direct distance. A larger ratio means that on average vehicles had to detour more, i.e. vehicles had to travel more for a given origin and destination.

As can be seen in Figure 7, the total distance rose for cars and HGVs after the opening of DPT, from $917713 \mathrm{~km}$ to $917663 \mathrm{~km}$ and from $72755 \mathrm{~km}$ to $84605 \mathrm{~km}$, respectively. The implementation of the HGV management strategy also caused the total distance to rise further, from $917663 \mathrm{~km}$ to $917673 \mathrm{~km}$ and from $84605 \mathrm{~km}$ to $110012 \mathrm{~km}$ for cars and HGVs respectively. On the other hand, the direct distance required to meet travel demands for these three scenarios were the same, because these scenarios all used the same OD matrices. In the scenario 2007 DPT+Ban, total distance and direct distance all increased while in the scenario of 2013 DPT+Ban the total distance and direct distance all decreased. As direct distance can reflect the level of travel demand, we can infer from the figure that the travel demand increased in 2007 and decreased in 2013.

As shown in Figure 8, ratio of total distance to direct distance didn't change after the DPT was opened and after the HGV strategy was implemented. In the 2007 and 2013 scenario, this ratio only had a very small change for cars compared to the ratios for HGVs. This shows that the DPT and the HGV management strategy did not have a significant impact on cars. However for HGVs, this ratio increased from 1.50 to 1.74 and then surged to 2.27 after the opening of the DPT and the implementation of the HGV strategy. This was an increase of by $16 \%$ and $51 \%$, respectively. In the 2007 and 2013 scenarios, the ratio for HGVs were both higher than 2.0. These ratios show that the DPT and the HGV strategy affected the route of HGVs a lot and resulted in HGVs detouring a lot. 


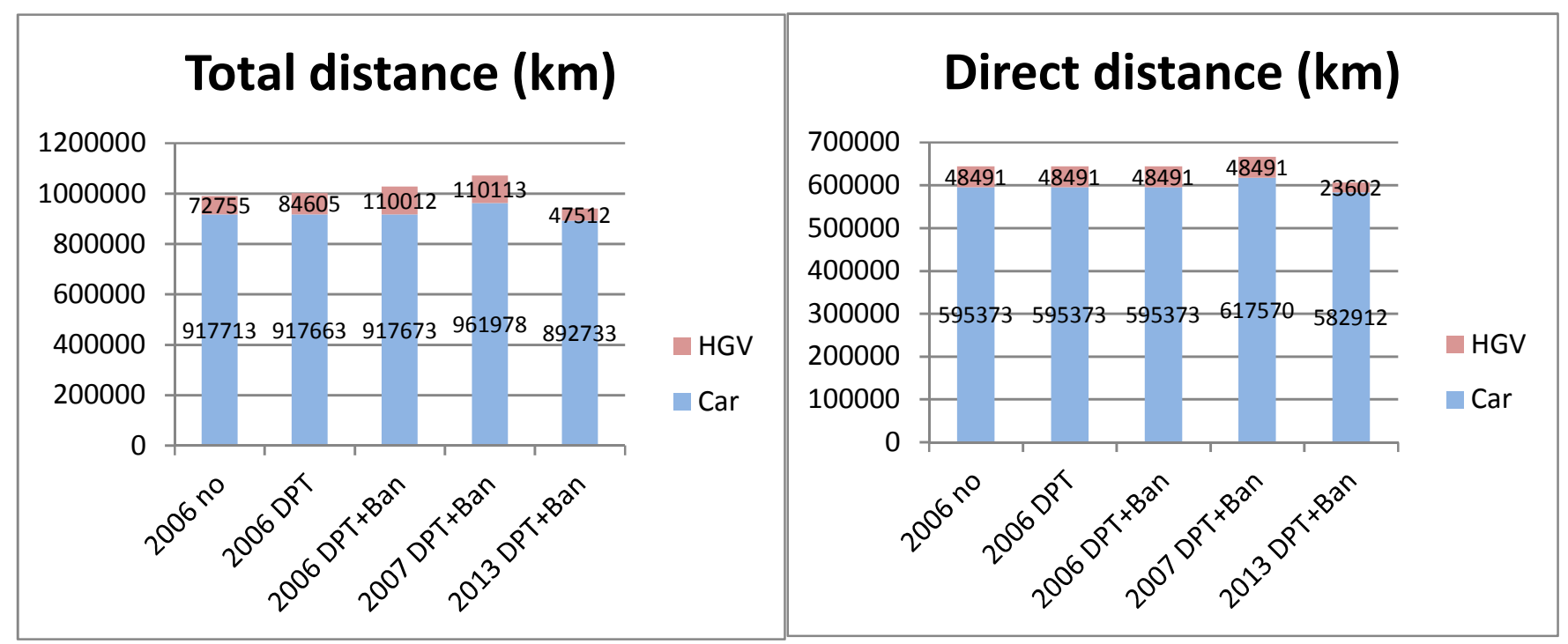

Fig. 7. Total distance and direct distance.

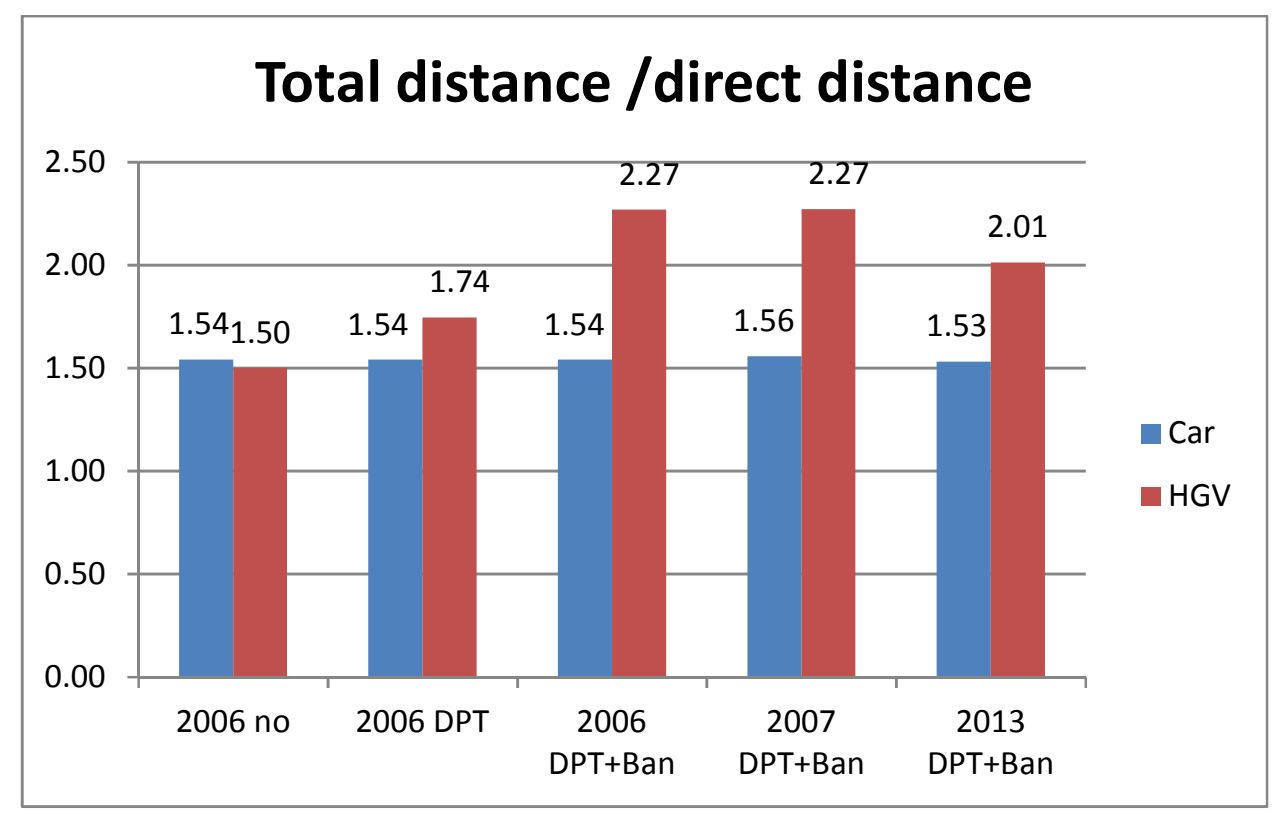

Fig. 8. The ratio of total distance to total direct distance.

The speed distributions of the different scenarios are depicted in Figure 9. Comparing 2006 no DPT, 2006 DPT, 2006 DPT+Ban and 2007 DPT+Ban scenarios, it can be observed that the proportions of low speed range $(5-35 \mathrm{~km} / \mathrm{h}$ ) for cars for all these four scenarios are around 0.53-0.55. However for HGVs, the proportions of low speed range declined after the HGV management, from about 0.460.48 for the former two scenarios to about 0.33-0.36 for the latter two scenarios. This means the latter two scenarios have higher proportions of middle and high speed range (35-65 and 65-95 km/h, respectively) so that there was less congestion for HGVs after the implementation of the HGV strategy. This implies that the DPT with the HGV management strategy together has a function to improve the average speed of the network by reducing congestion in the city centre, which would 
have obvious air pollution benefits. As for the scenarios in 2013, the proportion of middle and high speed ranges rose for cars and HGVs compared to previous scenarios, from more than 0.52 to 0.40 for cars and from more than 0.32 to 0.20 for HGVs. This was due in part to the fact that travel demand dropped in 2013 as we discussed earlier, due to economic factors.

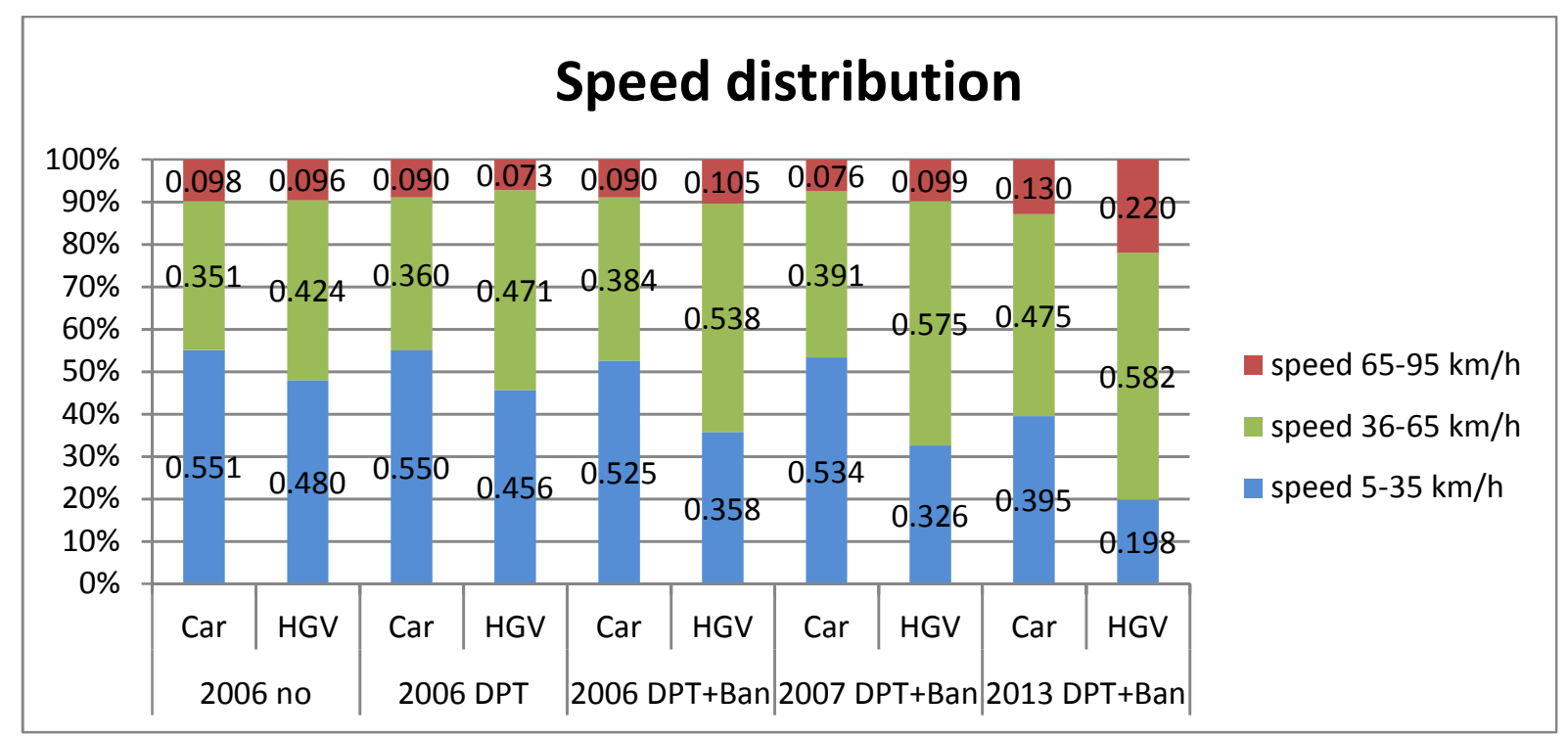

Fig. 9. Speed distribution.

\subsection{Emission calculation}

Figure 10 illustrates the total traffic emission trends for all scenarios. In the 2006 scenarios, in general, all pollutions were increased after the DPT was opened and after the HGV management was implemented. Using $\mathrm{NO}_{\mathrm{x}}$ as an example, the emission was $719.05 \mathrm{~kg}$ in the 2006 no DPT scenario. Then it increased to $775.36 \mathrm{~kg}$ in 2006 DPT scenario and again increased to $869.28 \mathrm{~kg}$ in the DPT+Ban scenario. It increased by $8 \%$ and $21 \%$. This implies that the DPT and the HGV strategy would make the total emission rise. This was due to the DPT and the HGV strategy forcing HGVs detour significantly during their trips. Although DPT with HGV strategy reduced the congestion in the city centre, the emission reduction brought about by this benefit was not compensated for by the emission growth brought about by the additional detours.

In the 2007 DPT+Ban scenario, the emission generally dropped for all pollutions except for $\mathrm{CO}_{2}$. Using NOx and PM as examples, comparing to 2006 DPT+Ban scenario, the NOx and PM emissions declined from $869.28 \mathrm{~kg}$ to $839.65 \mathrm{~kg}$ and from $30.71 \mathrm{~kg}$ to $28.82 \mathrm{~kg}$ respectively. However emission of $\mathrm{CO}_{2}$ rose from $240.75 \mathrm{t}$ to $250.58 \mathrm{t}$. The speed distribution of this scenario was similar to the 2006 DPT+Ban, but the total distance travelled by vehicles was more than the total distance in the scenario of 2006 DPT+Ban. The fleet distribution used in this scenario was for the year of 2007 while the 2006 DPT+Ban used 2006 fleet distribution. Comparing 2006 and 2007 DPT+Ban scenario, the similar speed distribution should have similar impact on emissions, and increased total distance should produce more emissions. We can infer therefore that the reduction in emissions was mainly caused by the technology improvement of fleet between these two years. Comparing to other 
pollutants, the emission of $\mathrm{CO}_{2}$ is less sensitive to the technology improvement and relies more on the travel distance.

The emissions in the 2013 scenario fell sharply. For example, for $\mathrm{CH}_{4}$ and $\mathrm{CO}$, the emissions of the 2013 scenario decreased to less than a half of the emissions of the 2007 scenario, from $8.07 \mathrm{~kg}$ to $2.74 \mathrm{~kg}$ and from $0.84 \mathrm{t}$ to $0.36 \mathrm{t}$ respectively. This reflected the joint impacts of the drop of total distance travelled, the improvement of speed distribution, and technology improvement of the fleet.

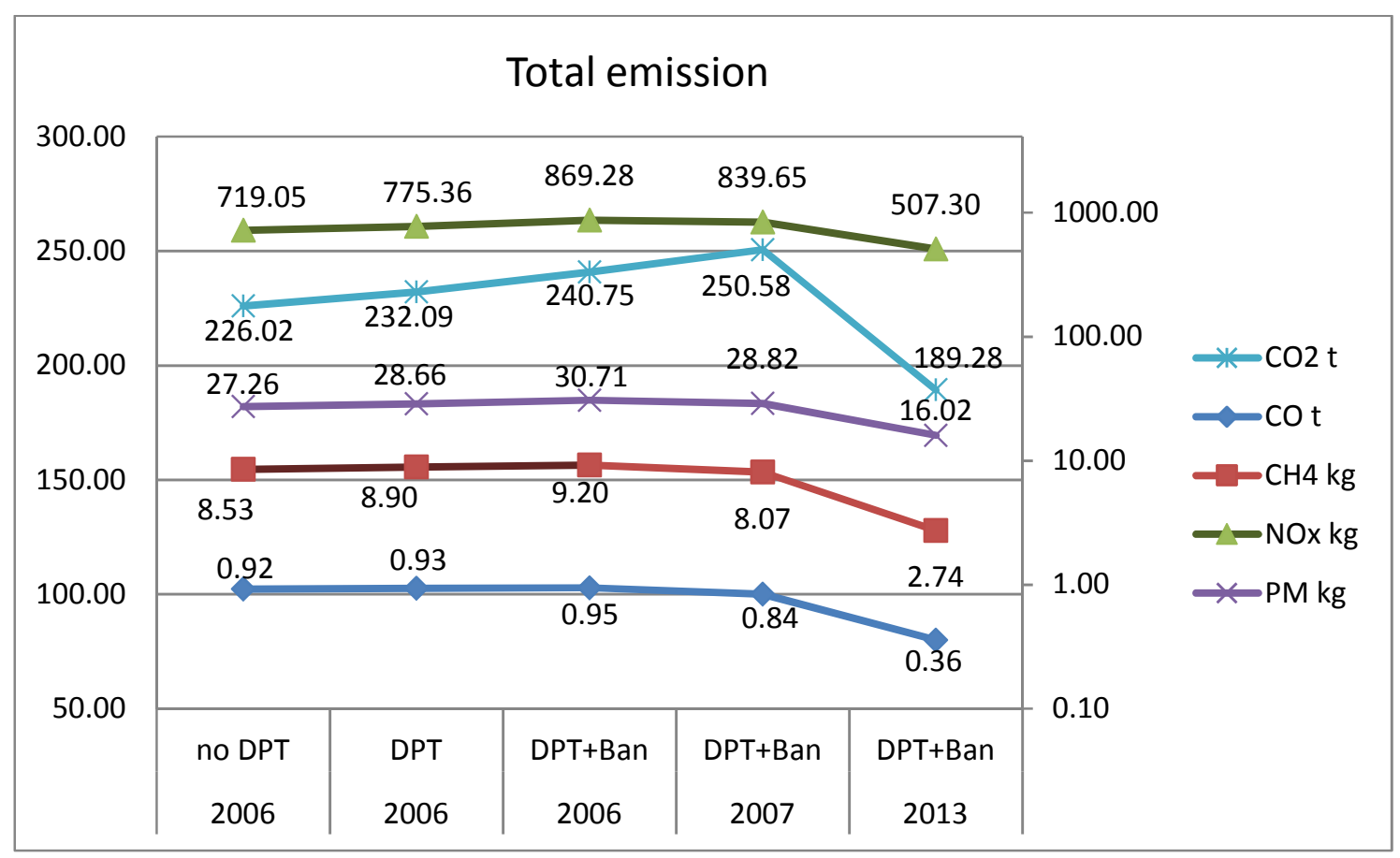

Fig. 10. Total emission trend.

The standardized emissions shown here were calculated as the ratio of total emission to direct distance. The result of the standardized emissions are displayed in Figure 11.

Comparing the three 2006 scenarios (i.e. 2006 no DPT, 2006 DPT and 2006 DPT+Ban) with each other, we can find that emissions for all pollutants remained similar for cars, about $1.4 \mathrm{~g} / \mathrm{km}$ for $\mathrm{CO}$, $10.2 \mathrm{mg} / \mathrm{km}$ for $\mathrm{CH}_{4}, 0.6 \mathrm{~g} / \mathrm{km}$ for $\mathrm{NOx}, 30.5 \mathrm{mg} / \mathrm{km}$ for PM, $317 \mathrm{~g} / \mathrm{km}$ for $\mathrm{CO}_{2}$. This was because the total distance travelled by vehicles and speed distributions were similar for cars across the scenarios and the fleet compositions were the same. However, although the three scenarios had the same fleet compositions for HGVs, the emissions for HGVs were different. Compared to the 2006 no DPT scenario, all the pollutants emissions were increased in the 2006 DPT scenario, and again increased further in the 2006 DPT+Ban scenario. Taking PM emissions from HGVs as an example, it was 185.8 $\mathrm{mg} / \mathrm{km}$ in the 2006 no DPT scenario, $215.4 \mathrm{mg} / \mathrm{km}$ in the 2006 DPT scenario, and was $261.0 \mathrm{mg} / \mathrm{km}$ in the 2006 DPT+Ban scenario. Although the proportion of low speed range for HGVs declined a little in the scenario of 2006 DPT+Ban, which implies that the congestion for HGVs abated, the standardised emissions of the 2006 DPT+Ban scenario was still the highest among the three 2006 scenarios. From this we can infer that the total distance travelled by vehicles plays a major role in affecting the standardised emissions in our three scenarios. For a given origin and destination, the 
more a vehicle detoured, the more pollutions the vehicle emitted. The ratio of the total distance to the direct distance for HGVs were 1.50, 1.74, and 2.27 for 2006 no DPT, 2006 DPT and 2006 DPT+Ban scenario, respectively. Therefore, due to the significantly longer travel distances, the improvement of speed and the reduction of congestion in the city centre did not offset the extra emission brought on by the extra distance for 2006 scenarios.

Regarding the three DPT+Ban scenarios, the results showed a decline of the emissions from cars for $\mathrm{CO}, \mathrm{CH}_{4}$ and PM. For instance, the $\mathrm{CO}$ emissions for the scenario of 2006, 2007 and 2013 DPT+Ban were $1.4 \mathrm{~g} / \mathrm{km}, 1.2 \mathrm{~g} / \mathrm{km}$ and $0.6 \mathrm{~g} / \mathrm{km}$ respectively. As for $\mathrm{NO}_{x}$, the three scenarios had the same emissions of $0.6 \mathrm{~g} / \mathrm{km}$. The emissions of $\mathrm{CO}_{2}$ for 2006, 2007 and 2013 scenario were $315.3 \mathrm{~g} / \mathrm{km}$, $321.2 \mathrm{~g} / \mathrm{km}$ and $288.2 \mathrm{~g} / \mathrm{km}$ for cars. The ratio of total distance to the direct distance was similar for these three scenarios. The speed distributions for the scenarios of 2006 and 2007 DPT+ Ban were also similar and both of them had a larger proportion of low speed range vehicles than the scenario of 2013 DPT+Ban. Thus part of the reason that the 2013 DPT+Ban scenario had lower standardised emissions was due to the improvement of speed distribution in the network. Another reason was that the vehicle fleet technology was improved.

Although the ratio of total distance to direct distance and the speed distribution in the 2006 DPT+Ban scenario were similar to 2007 DPT+Ban, the emission of $\mathrm{CO}, \mathrm{CH}_{4}$ and reduced. This was due to the technology improvement in the vehicle fleet between 2006 and 2007. I can be seen that these reductions in emissions were quite modest at 3-6\%.

For the emissions from HGVs, emissions of all the pollutants decreased from 2006. As the scenario of 2013 DPT+Ban had small ratio of total distance to direct distance, optimized speed distribution and improved technology for HGVs, all of these resulted in the lowest standardised emission for HGVs among the DPT+Ban scenarios. 
Emissions / direct distance

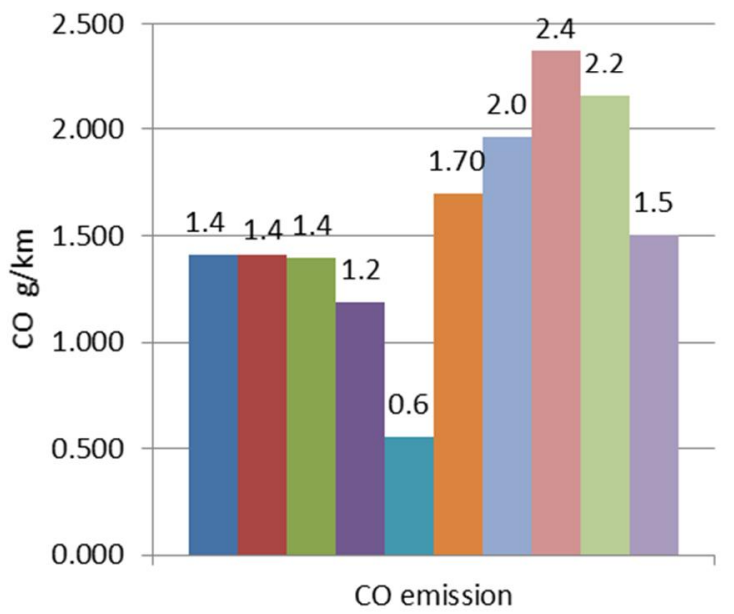

$$
\begin{aligned}
& =2006 \text { no DPT Car } \\
& \square 2006 \text { DPT Car } \\
& \square 2006 \text { DPT+Ban Car } \\
& \square 2007 \text { DPT+Ban Car } \\
& \square 2013 \text { DPT+Ban Car } \\
& \square 2006 \text { no DPT HGV } \\
& \square 2006 \text { DPT HGV } \\
& \square 2006 \text { DPT+Ban HGV } \\
& \square 2007 \text { DPT+Ban HGV } \\
& \square 2013 \text { DPT+Ban HGV }
\end{aligned}
$$
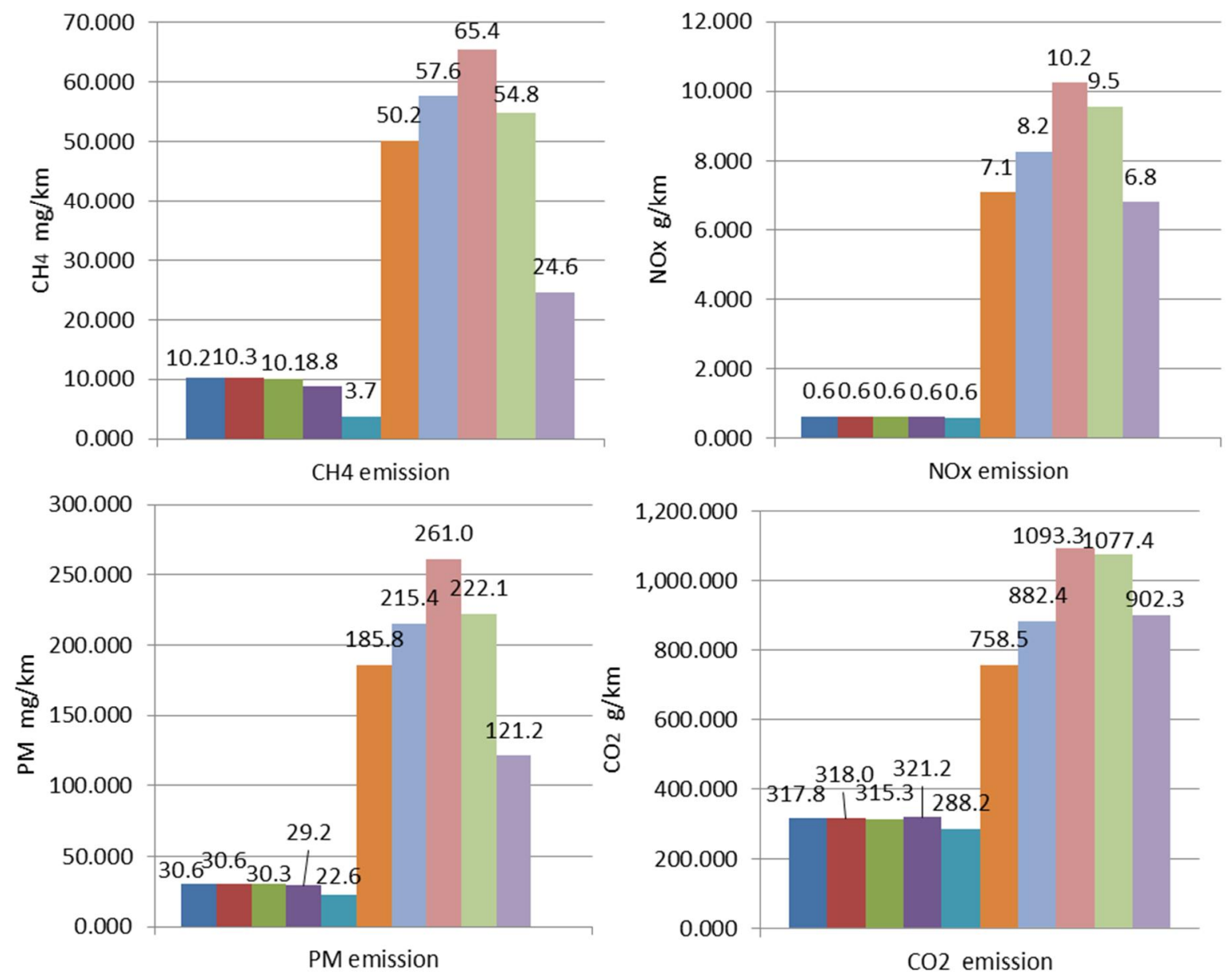

Fig. 11. Standardized emissions for different scenarios.

\section{Discussion}

The impact of the DPT and HGV management strategy can be inferred from the comparison of the different scenarios simulated in this paper. The impact of DPT on traffic and emission in Dublin city were estimated by comparing the scenario of 2006 no DPT to 2006 DPT. The impact of HGV 
management strategy was evaluated by the comparison of the hypothetical 2006 DPT+Ban scenario and 2006 DPT scenario. Scenarios for 2007 and 2013 were also simulated in the paper to investigate the effect in this context of emission changes over time and the impact of vehicle technology improvements.

From the comparison of the 2007 DPT+Ban scenario and the 2013 DPT+Ban scenario, we can infer that for the same road network capacity, less travel demand can improve speed distribution and average speed in the network. From this aspect, in the situations when the travel demand is difficult to reduce, it is useful to construct more roads to improve the network capacity and thus reduce congestion. On the other hand, from the comparison of 2006 DPT and 2006 no DPT, a new road could cause vehicles to detour and travel longer. A trade-off between these two potential impacts brought by a new road should be carefully considered.

By comparing the three 2006 scenarios, we can infer that the DPT and the HGV management strategy both had an impact on the average distance travelled by vehicles. The HGV strategy improved the speed distribution of vehicles in the network. However the benefit of the emission reduction brought about by this improvement could not offset the disadvantage of the emission growth brought about by the longer travel distances. Therefore in total, the DPT and the HGV strategy increased the total traffic emissions, considering the whole road network of the greater Dublin Area.

By comparing the three DPT+Ban scenarios, we found that the vehicle fleet technology improvement from 2006 to 2013 had a positive impact on emission reduction. As discussed in section 3.2, the standardized emission for HGVs for the scenario 2013 DPT+Ban was lower than 2007 DPT+Ban and HGV emission for the scenario 2007 DPT+Ban was lower than 2006 DPT+Ban. This could be caused by two reasons: vehicle emissions technology improvements and speed improvement. It can be seen in Table S2, compared to 2006, the proportions of vehicles that applied Euro 3 and Euro 4 standards in 2007 and vehicles that applied Euro 4 and Euro 5 standards in 2013 have increased, while vehicle numbers applying Euro 1 and Euro 2 fell. Euro 3, 4, and 5 standards implement more strict emission controls than Euro 1 and Euro 2, and significant efforts have been made to reduce emissions from vehicles during this period (e.g. introduction of diesel particle filters).

An obvious impact of these emissions is the potential health effects on the urban population. As can be seen from our traffic model, after the opening of the DPT and the implementation of HGV management strategy, traffic reductions have been found in the city centre where population density is relatively high. Also, as mentioned in the introduction to this paper, an air quality monitor in the city centre witnessed a significant reduction in average daily $\mathrm{PM}_{10}$ concentration after the opening of the DPT and the implementation of HGV management strategy. From this aspect, the DPT and HGV strategy therefore could have resulted in some health benefits to the population. However, the total emissions after the opening of the DPT and the implementation of HGV management strategy were increased. Thus it is difficult to assert whether the DPT and the HGV strategy have brought about benefits to health of the populations or not. Such an outcome is a further example of the nexus between climate change and air pollution policy (Bollen \& Brink, 2014), where in this case the regulatory and infrastructure changes implemented in Dublin have resulted in improved city centre air quality but at the cost of increased $\mathrm{CO}_{2}$ emissions and potential climate change impacts, as well as increased air pollution outside the city centre.

Some cities like London have implemented low emission zones (LEZ) which charge vehicles that do not meet the LEZ emissions standards travelling within the LEZ. This policy can make some vehicles that are originally planning to travel within the LEZ choose another route, causing detours. The 
impact of such a policy is similar to the HGV management strategy which reduces the traffic within the strategy implementation area whilst causing some vehicles to travel for a longer distance. As mentioned in Section 1, the air quality improvements within the LEZ were observed after the implementation of LEZ. However, like the HGV strategy, if we consider the whole area that is potentially affected by the LEZ, it may not always the case that the LEZ will improve the environment as a whole. Dias et al. (2016) supported this finding when they modelled the emissions change that could be brought about by using an LEZ in the city of Coimbra in Portugal. They found that $\mathrm{PM}_{10}$ and $\mathrm{NO}_{2}$ emissions from private cars would decrease significantly inside the LEZ (63\% and 52\%, respectively). However, in contrast, total emissions would increase and a deterioration of air quality was expected to occur at city level.

This paper showed that infrastructural or policy changes that affect traffic flow should be appraised for their effects on the road network as a whole. Emissions from detours are a major factor that could influence the outcome of policy or infrastructure change. Examples of these changes include new road construction, LEZ, tolling systems, licence plate restriction policy, HGV management strategy, and so on. This paper also demonstrated an appraisement method that could be used when estimating the traffic and the emission changes of a city.

\section{Conclusion}

According to the results of this study, the opening of the DPT and the introduction of the HGV strategy influenced the speed distribution and travel distance of vehicles, which all have an impact on the emission of air pollutants. While the HGV management strategy improved speed distributions, it made HGVs travel further as the ratios of total distance to direct distance increased.

From the study results, it can be seen that the DPT and HGV management strategy reduced the traffic in the city centre while also forcing vehicles to travel further, thereby increasing the total emissions. The HGV management improved the overall speed distribution of the network. Travel demand reductions from 2006 to 2013 also improved the speed distribution. Emissions reduced significantly from 2006 to 2013 and fleet technology improvements had a positive impact on this reduction.

Regarding the emissions, the construction of a new road should be appraised carefully. An analysis of the traffic condition of the existing road network is necessary. For a heavily congested city, the benefit of speed optimisation brought about by a new bypass may surpass the disadvantage of adding extra distance for the same trip. For a city which does not have heavy traffic, a bypass could bring about a negative effect.

A bypass that helps to reduce the emissions in a city centre location, for example, may not reduce the total emissions in a network as the travel demand remains, resulting in detours. The findings of this study are also relevant to other transport policies whereby travel restrictions are placed on small areas of a road network (e.g. the city centre) with the potential to cause significant detouring of traffic, such as low emissions zones. 


\section{Acknowledgement}

The author would like to acknowledge the financial supports from Trinity College Dublin. The Irish National Roads Authority and Dublin City Council are acknowledged for providing modelling data, as well as the PTV company for the software and their technical support.

\section{References}

Bandeira, J., Almeida, T.G., Khattak, A.J., Rouphail, N.M. \& Coelho, M.C., 2013. Generating emissions information for route selection: Experimental monitoring and routes characterization. Journal of Intelligent Transportation Systems, 17(1), pp.3-17.

Bollen, J. \& Brink, C. 2014. Air pollution policy in Europe: Quantifying the interaction with greenhouse gases and climate change policies. Energy Economics, 46, 202-215.

Cyrys, J., Peters, A. \& Wichmann, H. 2009, "Low emission zone munich - first results", Umweltmedizin in Forschung und Praxis, vol. 14, no. 3, pp. 127-132.

CSO. 2011. Population of each Province, County and City, 2011 [Online]. Central Statistics Office. Department of the Environment Heritage and Local Government. 2007. National Climate Change Strategy 2007 - 2012 [Online]. Available: http://www.environ.ie/en/Publications/Environment/Atmosphere/FileDownLoad,1861,en.p df.

Dias, D., Tchepel, O. and Antunes, A.P., 2016. Integrated modelling approach for the evaluation of low emission zones. Journal of environmental management, 177, pp.253-263.

EEA 2013a. Air quality in Europe - 2013 report. EEA report no 9/2013, European Environmental Agency.

EEA 2013b. European Union emission inventory report 1990-2011 under the UNECE Convention on Long-range Transboundary Air Pollution (LRTAP). EEA technical report no 10/2013. European Environmental Agency.

Ellison, R. B., Greaves, S. P., \& Hensher, D. A., 2013. Five years of London's low emission zone: Effects on vehicle fleet composition and air quality. Transportation Research Part D: Transport and Environment, 23, 25-33. http://doi.org/10.1016/j.trd.2013.03.010

Finnegan, C., O'brien, B. \& Traynor, D. 2007. An initial evaluation of Dublin port tunnel and the HGV management strategy for the city. Proceedings of the European transport conference 2007 held 17-19 October 2007, Leiden, the Netherlands.

Ireland EPA, 2015. Ireland National Inventory Report -- Green House Emissions 1990-2013.

Leo, V. 2012. Road Traffic (Ordinary Speed Limits - Buses, Heavy Goods Vehicles, Etc.) (Amendment) Regulations 2012. Iris Oifigiúil.

Leon, N. \& Zissis, S. 2014. COPERT 4 -- Methodology for the calculation of exhaust emissions. European Environment Agency.

Lozano, A., Granados, F., \& Guzmán, A., 2014. Impacts of Modifications on Urban Road Infrastructure and Traffic Management: A Case Study. Procedia - Social and Behavioral Sciences, 162, 368-377. http://doi.org/10.1016/j.sbspro.2014.12.218

NRA 2009. National Traffic Model -- Model Validation Report. National Roads Authority.

NRA 2014. National Trasport Model Volume 1 -- Model Development Report. National Roads Authority.

O’Brien, B. \& Bolger, N. 2009. HGV Management Strategy Review 2009. Roads and Traffic Department, Dublin City Council.

OECD 2003. Delivering the goods : 21st century challenges to urban goods transport, Paris, OECD. 
Pant, P. \& Harrison, R. M. 2013. Estimation of the contribution of road traffic emissions to particulate matter concentrations from field measurements: A review. Atmospheric Environment, 77, 78-97.

Pojani, D., \& Stead, D., 2015. Sustainable Urban Transport in the Developing World: Beyond Megacities. Sustainability, 7(6), 7784-7805. http://doi.org/10.3390/su7067784

$\mathrm{Pu}$, Y., Yang, C., Liu, H., Chen, Z. and Chen, A., 2015. Impact of license plate restriction policy on emission reduction in Hangzhou using a bottom-up approach. Transportation Research Part D: Transport and Environment, 34, pp.281-292.

PTV company 2014. PTV VISUM 14 Manual.

UK DMRB, 1997. Design Manual for Roads and Bridges: Volume 12, London. 


\section{Supplementary Materials}

Calibration criteria shown in Table S1:

\begin{tabular}{|lc|}
\hline Criteria and Measure & Guideline \\
\hline Modelled Hourly Flows vs. Observed traffic counts: & \\
\hline Individual flows within $15 \%$ for flows $700-2700 \mathrm{vph}$ & $>85 \%$ of cases \\
Individual flows within $100 \mathrm{vph}$ for flows $<700 \mathrm{vph}$ & \\
Individual flows within $400 \mathrm{vph}$ for flows $>2700$ & \\
\hline
\end{tabular}

Table S1. Calibration criteria (Adapted from UK DMRB, 1997)

Ireland fleet distribution shown in Table S2:

\begin{tabular}{|c|c|c|c|c|c|}
\hline Sector & Subsector & Technology & 2006 & 2007 & 2013 \\
\hline Passenger Cars & Gasoline 0,8 - 1,4 I & PRE ECE & 0 & 0 & 0 \\
\hline Passenger Cars & Gasoline 0,8 - 1,4 I & ECE 15/00-01 & 0 & 0 & 0 \\
\hline Passenger Cars & Gasoline 0,8 - 1,4 I & ECE 15/02 & 0 & 0 & 0 \\
\hline Passenger Cars & Gasoline $0,8-1,4$ I & ECE 15/03 & 0 & 0 & 0 \\
\hline Passenger Cars & Gasoline 0,8 - 1,4 I & ECE 15/04 & 15904 & 11489 & 949 \\
\hline Passenger Cars & Gasoline 0,8 - 1,4 I & Open Loop & 0 & 0 & 0 \\
\hline Passenger Cars & Gasoline $0,8-1,4$ I & PC Euro 1 - 91/441/EEC & 107123 & 77929 & 7739 \\
\hline Passenger Cars & Gasoline 0,8 - 1,4 I & PC Euro 2 - 94/12/EEC & 336491 & 307589 & 201061 \\
\hline Passenger Cars & Gasoline 0,8 - 1,4 I & $\begin{array}{l}\text { PC Euro } 3 \text { - 98/69/EC } \\
\text { Stage2000 }\end{array}$ & 266772 & 258354 & 276634 \\
\hline Passenger Cars & Gasoline 0,8 - 1,4 I & $\begin{array}{l}\text { PC Euro } 4 \text { - 98/69/EC } \\
\text { Stage2005 }\end{array}$ & 73236 & 143395 & 251944 \\
\hline Passenger Cars & Gasoline 0,8 - 1,4 I & $\begin{array}{l}\text { PC Euro } 5 \text { - EC } \\
715 / 2007\end{array}$ & 0 & 0 & 39297 \\
\hline Passenger Cars & Gasoline 0,8 - 1,4 I & $\begin{array}{l}\text { PC Euro } 6-E C \\
715 / 2007\end{array}$ & 0 & 0 & 0 \\
\hline Passenger Cars & Gasoline 1,4 - 2,0 I & PRE ECE & 0 & 0 & 0 \\
\hline Passenger Cars & Gasoline 1,4 - 2,0 I & ECE 15/00-01 & 0 & 0 & 0 \\
\hline Passenger Cars & Gasoline 1,4 - 2,0 I & ECE 15/02 & 0 & 0 & 0 \\
\hline Passenger Cars & Gasoline 1,4 - 2,0 I & ECE $15 / 03$ & 0 & 0 & 0 \\
\hline Passenger Cars & Gasoline 1,4 - 2,0 I & ECE 15/04 & 12265 & 9511 & 504 \\
\hline Passenger Cars & Gasoline 1,4 - 2,0 I & Open Loop & 0 & 0 & 0 \\
\hline Passenger Cars & Gasoline 1,4 - 2,0 I & PC Euro 1 - 91/441/EEC & 82616 & 64507 & 4434 \\
\hline Passenger Cars & Gasoline 1,4 - 2,0 I & PC Euro 2 - 94/12/EEC & 259509 & 254611 & 106786 \\
\hline Passenger Cars & Gasoline 1,4 - 2,0 I & $\begin{array}{l}\text { PC Euro } 3 \text { - 98/69/EC } \\
\text { Stage2000 }\end{array}$ & 205741 & 213856 & 146907 \\
\hline Passenger Cars & Gasoline 1,4 - 2,0 I & $\begin{array}{l}\text { PC Euro } 4 \text { - 98/69/EC } \\
\text { Stage2005 }\end{array}$ & 56481 & 118698 & 136307 \\
\hline Passenger Cars & Gasoline 1,4 - 2,0 I & $\begin{array}{l}\text { PC Euro } 5-E C \\
715 / 2007\end{array}$ & 0 & 0 & 21812 \\
\hline Passenger Cars & Gasoline 1,4 - 2,0 I & $\begin{array}{l}\text { PC Euro } 6 \text { - EC } \\
715 / 2007\end{array}$ & 0 & 0 & 0 \\
\hline Passenger Cars & Gasoline $>2,0$ I & PRE ECE & 0 & 0 & 0 \\
\hline
\end{tabular}




\begin{tabular}{|c|c|c|c|c|c|}
\hline Passenger Cars & Gasoline $>2,0$ I & ECE 15/00-01 & 0 & 0 & 0 \\
\hline Passenger Cars & Gasoline $>2,0 \mathrm{I}$ & ECE 15/02 & 0 & 0 & 0 \\
\hline Passenger Cars & Gasoline $>2,0$ I & ECE 15/03 & 0 & 0 & 0 \\
\hline Passenger Cars & Gasoline $>2,0 \mathrm{I}$ & ECE 15/04 & 1621 & 1353 & 33 \\
\hline Passenger Cars & Gasoline $>2,0 \mathrm{I}$ & PC Euro 1 - 91/441/EEC & 10921 & 9174 & 425 \\
\hline Passenger Cars & Gasoline $>2,0 \mathrm{I}$ & PC Euro 2 - 94/12/EEC & 34305 & 36208 & 7055 \\
\hline Passenger Cars & Gasoline $>2,0$ I & $\begin{array}{l}\text { PC Euro } 3 \text { - 98/69/EC } \\
\text { Stage2000 }\end{array}$ & 27197 & 30413 & 9699 \\
\hline Passenger Cars & Gasoline $>2,0$ I & $\begin{array}{l}\text { PC Euro } 4 \text { - 98/69/EC } \\
\text { Stage2005 }\end{array}$ & 7466 & 16880 & 9733 \\
\hline Passenger Cars & Gasoline $>2,0$ I & $\begin{array}{l}\text { PC Euro } 5 \text { - EC } \\
715 / 2007\end{array}$ & 0 & 0 & 1723 \\
\hline Passenger Cars & Gasoline $>2,0$ I & $\begin{array}{l}\text { PC Euro } 6 \text { - EC } \\
715 / 2007\end{array}$ & 0 & 0 & 0 \\
\hline Passenger Cars & Diesel 1,4 - 2,0 I & Conventional & 5187 & 4309 & 182 \\
\hline Passenger Cars & Diesel 1,4 - 2,0 I & PC Euro 1 - 91/441/EEC & 34938 & 29228 & 1452 \\
\hline Passenger Cars & Diesel 1,4 - 2,0 I & PC Euro 2 - 94/12/EEC & 109746 & 115363 & 38544 \\
\hline Passenger Cars & Diesel 1,4 - 2,0 I & $\begin{array}{l}\text { PC Euro } 3 \text { - 98/69/EC } \\
\text { Stage2000 }\end{array}$ & 87007 & 96897 & 132268 \\
\hline Passenger Cars & Diesel 1,4 - 2,0 I & $\begin{array}{l}\text { PC Euro } 4 \text { - 98/69/EC } \\
\text { Stage2005 }\end{array}$ & 23886 & 53781 & 288016 \\
\hline Passenger Cars & Diesel 1,4 - 2,0 I & $\begin{array}{l}\text { PC Euro } 5 \text { - EC } \\
715 / 2007\end{array}$ & 0 & 0 & 160045 \\
\hline Passenger Cars & Diesel 1,4 - 2,0 I & $\begin{array}{l}\text { PC Euro } 6 \text { - EC } \\
715 / 2007\end{array}$ & 0 & 0 & 0 \\
\hline Passenger Cars & Diesel $>2,0$ I & Conventional & 844 & 760 & 26 \\
\hline Passenger Cars & Diesel $>2,0$ I & PC Euro 1 - 91/441/EEC & 5688 & 5158 & 209 \\
\hline Passenger Cars & Diesel $>2,0$ I & PC Euro 2 - 94/12/EEC & 17866 & 20358 & 5545 \\
\hline Passenger Cars & Diesel $>2,0$ I & $\begin{array}{l}\text { PC Euro } 3 \text { - 98/69/EC } \\
\text { Stage2000 }\end{array}$ & 14164 & 17100 & 19029 \\
\hline Passenger Cars & Diesel $>2,0$ I & $\begin{array}{l}\text { PC Euro } 4 \text { - 98/69/EC } \\
\text { Stage2005 }\end{array}$ & 3888 & 9491 & 41435 \\
\hline Passenger Cars & Diesel $>2,0$ I & $\begin{array}{l}\text { PC Euro } 5 \text { - EC } \\
715 / 2007\end{array}$ & 0 & 0 & 23025 \\
\hline Passenger Cars & Diesel $>2,0$ I & $\begin{array}{l}\text { PC Euro } 6-E C \\
715 / 2007\end{array}$ & 0 & 0 & 0 \\
\hline Passenger Cars & LPG & Conventional & 0 & 0 & 0 \\
\hline Passenger Cars & LPG & PC Euro 1 - 91/441/EEC & 196 & 183 & 72 \\
\hline Passenger Cars & LPG & PC Euro 2 - 94/12/EEC & 151 & 137 & 57 \\
\hline Passenger Cars & LPG & $\begin{array}{l}\text { PC Euro } 3 \text { - 98/69/EC } \\
\text { Stage2000 }\end{array}$ & 83 & 81 & 57 \\
\hline Passenger Cars & LPG & $\begin{array}{l}\text { PC Euro } 4 \text { - 98/69/EC } \\
\text { Stage2005 }\end{array}$ & 83 & 81 & 57 \\
\hline Passenger Cars & LPG & $\begin{array}{l}\text { PC Euro } 5 \text { - EC } \\
715 / 2007\end{array}$ & 0 & 0 & 0 \\
\hline Passenger Cars & LPG & $\begin{array}{l}\text { PC Euro } 6-E C \\
715 / 2007\end{array}$ & 0 & 0 & 0 \\
\hline
\end{tabular}




\begin{tabular}{|c|c|c|c|c|c|}
\hline Passenger Cars & Hybrid Gasoline $<1,4$ I & $\begin{array}{l}\text { PC Euro } 4 \text { - 98/69/EC } \\
\text { Stage2005 }\end{array}$ & 0 & 0 & 0 \\
\hline Passenger Cars & $\begin{array}{l}\text { Hybrid Gasoline 1,4 - } \\
2,0 \mathrm{I}\end{array}$ & $\begin{array}{l}\text { PC Euro } 4 \text { - 98/69/EC } \\
\text { Stage2005 }\end{array}$ & 0 & 0 & 0 \\
\hline Passenger Cars & Hybrid Gasoline >2,0 I & $\begin{array}{l}\text { PC Euro } 4 \text { - 98/69/EC } \\
\text { Stage2005 }\end{array}$ & 0 & 0 & 0 \\
\hline $\begin{array}{l}\text { Light Commercial } \\
\text { Vehicles }\end{array}$ & Gasoline $<3,5 t$ & Conventional & 89 & 49 & 4 \\
\hline $\begin{array}{l}\text { Light Commercial } \\
\text { Vehicles }\end{array}$ & Gasoline $<3,5 t$ & LD Euro 1 - 93/59/EEC & 217 & 134 & 28 \\
\hline $\begin{array}{l}\text { Light Commercial } \\
\text { Vehicles }\end{array}$ & Gasoline $<3,5 t$ & LD Euro 2 - 96/69/EEC & 550 & 381 & 101 \\
\hline $\begin{array}{l}\text { Light Commercial } \\
\text { Vehicles }\end{array}$ & Gasoline $<3,5 t$ & $\begin{array}{l}\text { LD Euro } 3 \text { - 98/69/EC } \\
\text { Stage2000 }\end{array}$ & 661 & 496 & 236 \\
\hline $\begin{array}{l}\text { Light Commercial } \\
\text { Vehicles }\end{array}$ & Gasoline $<3,5 t$ & $\begin{array}{l}\text { LD Euro } 4 \text { - 98/69/EC } \\
\text { Stage2005 }\end{array}$ & 223 & 337 & 292 \\
\hline $\begin{array}{l}\text { Light Commercial } \\
\text { Vehicles }\end{array}$ & Gasoline $<3,5 t$ & $\begin{array}{l}\text { LD Euro } 5 \text { - } 2008 \\
\text { Standards }\end{array}$ & 0 & 0 & 78 \\
\hline $\begin{array}{l}\text { Light Commercial } \\
\text { Vehicles }\end{array}$ & Gasoline $<3,5 t$ & LD Euro 6 & 0 & 0 & 0 \\
\hline $\begin{array}{l}\text { Light Commercial } \\
\text { Vehicles }\end{array}$ & Diesel $<3,5 \mathrm{t}$ & Conventional & 14153 & 10621 & 1441 \\
\hline $\begin{array}{l}\text { Light Commercial } \\
\text { Vehicles }\end{array}$ & Diesel $<3,5 \mathrm{t}$ & LD Euro 1 - 93/59/EEC & 34690 & 29131 & 10951 \\
\hline $\begin{array}{l}\text { Light Commercial } \\
\text { Vehicles }\end{array}$ & Diesel $<3,5 \mathrm{t}$ & LD Euro 2 - 96/69/EEC & 87696 & 82841 & 39482 \\
\hline $\begin{array}{l}\text { Light Commercial } \\
\text { Vehicles }\end{array}$ & Diesel $<3,5 \mathrm{t}$ & $\begin{array}{l}\text { LD Euro } 3 \text { - 98/69/EC } \\
\text { Stage2000 }\end{array}$ & 105457 & 107724 & 92220 \\
\hline $\begin{array}{l}\text { Light Commercial } \\
\text { Vehicles }\end{array}$ & Diesel $<3,5 \mathrm{t}$ & $\begin{array}{l}\text { LD Euro } 4 \text { - 98/69/EC } \\
\text { Stage2005 }\end{array}$ & 35522 & 73131 & 113834 \\
\hline $\begin{array}{l}\text { Light Commercial } \\
\text { Vehicles }\end{array}$ & Diesel $<3,5 \mathrm{t}$ & $\begin{array}{l}\text { LD Euro } 5 \text { - } 2008 \\
\text { Standards }\end{array}$ & 0 & 0 & 30260 \\
\hline $\begin{array}{l}\text { Light Commercial } \\
\text { Vehicles }\end{array}$ & Diesel $<3,5 \mathrm{t}$ & LD Euro 6 & 0 & 0 & 0 \\
\hline Heavy Duty Trucks & Gasoline $>3,5 \mathrm{t}$ & Conventional & 53 & 44 & 24 \\
\hline Heavy Duty Trucks & Rigid $<=7,5 \mathrm{t}$ & Conventional & 785 & 589 & 108 \\
\hline Heavy Duty Trucks & Rigid $<=7,5 \mathrm{t}$ & $\begin{array}{l}\text { HD Euro I - 91/542/EEC } \\
\text { Stage I }\end{array}$ & 1205 & 986 & 287 \\
\hline Heavy Duty Trucks & Rigid $<=7,5 \mathrm{t}$ & $\begin{array}{l}\text { HD Euro II - 91/542/EEC } \\
\text { Stage II }\end{array}$ & 3593 & 3282 & 1228 \\
\hline Heavy Duty Trucks & Rigid $<=7,5 \mathrm{t}$ & $\begin{array}{l}\text { HD Euro III - } 2000 \\
\text { Standards }\end{array}$ & 4321 & 4267 & 2868 \\
\hline Heavy Duty Trucks & Rigid $<=7,5 \mathrm{t}$ & $\begin{array}{l}\text { HD Euro IV - } 2005 \\
\text { Standards }\end{array}$ & 1467 & 2897 & 3541 \\
\hline Heavy Duty Trucks & Rigid $<=7,5 \mathrm{t}$ & $\begin{array}{l}\text { HD Euro V - } 2008 \\
\text { Standards }\end{array}$ & 0 & 0 & 932 \\
\hline Heavy Duty Trucks & Rigid $<=7,5 \mathrm{t}$ & HD Euro VI & 0 & 0 & 0 \\
\hline Heavy Duty Trucks & Rigid 7,5 - $12 \mathrm{t}$ & Conventional & 1159 & 830 & 129 \\
\hline Heavy Duty Trucks & Rigid 7,5 - $12 \mathrm{t}$ & $\begin{array}{l}\text { HD Euro I - 91/542/EEC } \\
\text { Stage I }\end{array}$ & 1781 & 1389 & 345 \\
\hline
\end{tabular}




\begin{tabular}{|c|c|c|c|c|c|}
\hline Heavy Duty Trucks & Rigid $7,5-12 t$ & $\begin{array}{l}\text { HD Euro II - 91/542/EEC } \\
\text { Stage II }\end{array}$ & 5308 & 4626 & 1477 \\
\hline Heavy Duty Trucks & Rigid $7,5-12 t$ & $\begin{array}{l}\text { HD Euro III - } 2000 \\
\text { Standards }\end{array}$ & 6384 & 6015 & 3450 \\
\hline Heavy Duty Trucks & Rigid $7,5-12 t$ & $\begin{array}{l}\text { HD Euro IV - } 2005 \\
\text { Standards }\end{array}$ & 2167 & 4084 & 4258 \\
\hline Heavy Duty Trucks & Rigid $7,5-12 t$ & $\begin{array}{l}\text { HD Euro V - } 2008 \\
\text { Standards }\end{array}$ & 0 & 0 & 1121 \\
\hline Heavy Duty Trucks & Rigid $7,5-12 \mathrm{t}$ & HD Euro VI & 0 & 0 & 0 \\
\hline Heavy Duty Trucks & Rigid $12-14 t$ & Conventional & 542 & 401 & 66 \\
\hline Heavy Duty Trucks & Rigid $12-14 t$ & $\begin{array}{l}\text { HD Euro I - 91/542/EEC } \\
\text { Stage I }\end{array}$ & 832 & 671 & 176 \\
\hline Heavy Duty Trucks & Rigid $12-14 t$ & $\begin{array}{l}\text { HD Euro II - 91/542/EEC } \\
\text { Stage II }\end{array}$ & 2481 & 2234 & 754 \\
\hline Heavy Duty Trucks & Rigid $12-14 t$ & $\begin{array}{l}\text { HD Euro III - } 2000 \\
\text { Standards }\end{array}$ & 2983 & 2905 & 1761 \\
\hline Heavy Duty Trucks & Rigid $12-14 t$ & $\begin{array}{l}\text { HD Euro IV - } 2005 \\
\text { Standards }\end{array}$ & 1013 & 1972 & 2173 \\
\hline Heavy Duty Trucks & Rigid $12-14 \mathrm{t}$ & $\begin{array}{l}\text { HD Euro V - } 2008 \\
\text { Standards }\end{array}$ & 0 & 0 & 572 \\
\hline Heavy Duty Trucks & Rigid $12-14 t$ & HD Euro VI & 0 & 0 & 0 \\
\hline Heavy Duty Trucks & Rigid $14-20 t$ & Conventional & 226 & 187 & 43 \\
\hline Heavy Duty Trucks & Rigid $14-20 t$ & $\begin{array}{l}\text { HD Euro I - 91/542/EEC } \\
\text { Stage I }\end{array}$ & 347 & 314 & 114 \\
\hline Heavy Duty Trucks & Rigid $14-20 t$ & $\begin{array}{l}\text { HD Euro II - 91/542/EEC } \\
\text { Stage II }\end{array}$ & 1036 & 1044 & 487 \\
\hline Heavy Duty Trucks & Rigid $14-20 t$ & $\begin{array}{l}\text { HD Euro III - } 2000 \\
\text { Standards }\end{array}$ & 1245 & 1358 & 1137 \\
\hline Heavy Duty Trucks & Rigid $14-20 t$ & $\begin{array}{l}\text { HD Euro IV - } 2005 \\
\text { Standards }\end{array}$ & 423 & 922 & 1403 \\
\hline Heavy Duty Trucks & Rigid $14-20 t$ & $\begin{array}{l}\text { HD Euro V - } 2008 \\
\text { Standards }\end{array}$ & 0 & 0 & 370 \\
\hline Heavy Duty Trucks & Rigid $14-20 t$ & HD Euro VI & 0 & 0 & 0 \\
\hline Heavy Duty Trucks & Rigid $20-26 \mathrm{t}$ & Conventional & 1 & 0 & 0 \\
\hline Heavy Duty Trucks & Rigid $20-26 t$ & $\begin{array}{l}\text { HD Euro I - 91/542/EEC } \\
\text { Stage I }\end{array}$ & 1 & 1 & 0 \\
\hline Heavy Duty Trucks & Rigid $20-26 \mathrm{t}$ & $\begin{array}{l}\text { HD Euro II - 91/542/EEC } \\
\text { Stage II }\end{array}$ & 3 & 2 & 1 \\
\hline Heavy Duty Trucks & Rigid $20-26 \mathrm{t}$ & $\begin{array}{l}\text { HD Euro III - } 2000 \\
\text { Standards }\end{array}$ & 3 & 3 & 3 \\
\hline Heavy Duty Trucks & Rigid $20-26 \mathrm{t}$ & $\begin{array}{l}\text { HD Euro IV - } 2005 \\
\text { Standards }\end{array}$ & 1 & 2 & 4 \\
\hline Heavy Duty Trucks & Rigid $20-26 t$ & $\begin{array}{l}\text { HD Euro V - } 2008 \\
\text { Standards }\end{array}$ & 0 & 0 & 1 \\
\hline Heavy Duty Trucks & Rigid $20-26 t$ & HD Euro VI & 0 & 0 & 0 \\
\hline Heavy Duty Trucks & Rigid $26-28 \mathrm{t}$ & Conventional & 1 & 0 & 0 \\
\hline Heavy Duty Trucks & Rigid $26-28 \mathrm{t}$ & $\begin{array}{l}\text { HD Euro I - 91/542/EEC } \\
\text { Stage I }\end{array}$ & 1 & 1 & 0 \\
\hline
\end{tabular}




\begin{tabular}{|c|c|c|c|c|c|}
\hline Heavy Duty Trucks & Rigid $26-28 t$ & $\begin{array}{l}\text { HD Euro II - 91/542/EEC } \\
\text { Stage II }\end{array}$ & 3 & 2 & 1 \\
\hline Heavy Duty Trucks & Rigid $26-28 t$ & $\begin{array}{l}\text { HD Euro III - } 2000 \\
\text { Standards }\end{array}$ & 3 & 3 & 3 \\
\hline Heavy Duty Trucks & Rigid $26-28 t$ & $\begin{array}{l}\text { HD Euro IV - } 2005 \\
\text { Standards }\end{array}$ & 1 & 2 & 4 \\
\hline Heavy Duty Trucks & Rigid $26-28 t$ & $\begin{array}{l}\text { HD Euro V - } 2008 \\
\text { Standards }\end{array}$ & 0 & 0 & 1 \\
\hline Heavy Duty Trucks & Rigid $26-28 \mathrm{t}$ & HD Euro VI & 0 & 0 & 0 \\
\hline Heavy Duty Trucks & Rigid $28-32 \mathrm{t}$ & Conventional & 1 & 0 & 0 \\
\hline Heavy Duty Trucks & Rigid $28-32 \mathrm{t}$ & $\begin{array}{l}\text { HD Euro I - 91/542/EEC } \\
\text { Stage I }\end{array}$ & 1 & 1 & 0 \\
\hline Heavy Duty Trucks & Rigid $28-32 t$ & $\begin{array}{l}\text { HD Euro II - 91/542/EEC } \\
\text { Stage II }\end{array}$ & 3 & 2 & 1 \\
\hline Heavy Duty Trucks & Rigid $28-32 t$ & $\begin{array}{l}\text { HD Euro III - } 2000 \\
\text { Standards }\end{array}$ & 3 & 3 & 3 \\
\hline Heavy Duty Trucks & Rigid $28-32 \mathrm{t}$ & $\begin{array}{l}\text { HD Euro IV - } 2005 \\
\text { Standards }\end{array}$ & 1 & 2 & 4 \\
\hline Heavy Duty Trucks & Rigid $28-32 \mathrm{t}$ & $\begin{array}{l}\text { HD Euro V - } 2008 \\
\text { Standards }\end{array}$ & 0 & 0 & 1 \\
\hline Heavy Duty Trucks & Rigid $28-32 \mathrm{t}$ & HD Euro VI & 0 & 0 & 0 \\
\hline Heavy Duty Trucks & Rigid $>32 t$ & Conventional & 1 & 0 & 0 \\
\hline Heavy Duty Trucks & Rigid $>32 t$ & $\begin{array}{l}\text { HD Euro I - 91/542/EEC } \\
\text { Stage I }\end{array}$ & 1 & 1 & 0 \\
\hline Heavy Duty Trucks & Rigid $>32 t$ & $\begin{array}{l}\text { HD Euro II - 91/542/EEC } \\
\text { Stage II }\end{array}$ & 3 & 2 & 1 \\
\hline Heavy Duty Trucks & Rigid $>32 t$ & $\begin{array}{l}\text { HD Euro III - } 2000 \\
\text { Standards }\end{array}$ & 3 & 3 & 3 \\
\hline Heavy Duty Trucks & Rigid $>32 t$ & $\begin{array}{l}\text { HD Euro IV - } 2005 \\
\text { Standards }\end{array}$ & 1 & 2 & 4 \\
\hline Heavy Duty Trucks & Rigid $>32 t$ & $\begin{array}{l}\text { HD Euro V - } 2008 \\
\text { Standards }\end{array}$ & 0 & 0 & 1 \\
\hline Heavy Duty Trucks & Rigid $>32 t$ & HD Euro VI & 0 & 0 & 0 \\
\hline Heavy Duty Trucks & Articulated $40-50 t$ & Conventional & 1 & 0 & 0 \\
\hline Heavy Duty Trucks & Articulated $40-50 \mathrm{t}$ & $\begin{array}{l}\text { HD Euro I - 91/542/EEC } \\
\text { Stage I }\end{array}$ & 1 & 1 & 0 \\
\hline Heavy Duty Trucks & Articulated $40-50 \mathrm{t}$ & $\begin{array}{l}\text { HD Euro II - 91/542/EEC } \\
\text { Stage II }\end{array}$ & 3 & 2 & 1 \\
\hline Heavy Duty Trucks & Articulated $40-50 \mathrm{t}$ & $\begin{array}{l}\text { HD Euro III - } 2000 \\
\text { Standards }\end{array}$ & 3 & 3 & 3 \\
\hline Heavy Duty Trucks & Articulated $40-50 \mathrm{t}$ & $\begin{array}{l}\text { HD Euro IV - } 2005 \\
\text { Standards }\end{array}$ & 1 & 2 & 4 \\
\hline Heavy Duty Trucks & Articulated $40-50 \mathrm{t}$ & $\begin{array}{l}\text { HD Euro V - } 2008 \\
\text { Standards }\end{array}$ & 0 & 0 & 1 \\
\hline Heavy Duty Trucks & Articulated $40-50 \mathrm{t}$ & HD Euro VI & 0 & 0 & 0 \\
\hline Heavy Duty Trucks & Articulated $50-60 t$ & Conventional & 1 & 0 & 0 \\
\hline Heavy Duty Trucks & Articulated $50-60 t$ & $\begin{array}{l}\text { HD Euro I - 91/542/EEC } \\
\text { Stage I }\end{array}$ & 1 & 1 & 0 \\
\hline
\end{tabular}




\begin{tabular}{|l|l|l|l|l|l|}
\hline Heavy Duty Trucks & Articulated 50 - 60 t & $\begin{array}{l}\text { HD Euro II - 91/542/EEC } \\
\text { Stage II }\end{array}$ & 3 & 2 & 1 \\
\hline Heavy Duty Trucks & Articulated 50 - 60 t & $\begin{array}{l}\text { HD Euro III - 2000 } \\
\text { Standards }\end{array}$ & 3 & 3 & 3 \\
\hline Heavy Duty Trucks & Articulated 50 - 60 t & $\begin{array}{l}\text { HD Euro IV - 2005 } \\
\text { Standards }\end{array}$ & 1 & 2 & 4 \\
\hline Heavy Duty Trucks & Articulated 50 - 60 t & $\begin{array}{l}\text { HD Euro V - 2008 } \\
\text { Standards }\end{array}$ & 0 & 0 & 1 \\
\hline Heavy Duty Trucks & Articulated 50 - 60 t & HD Euro VI & 0 & 0 & 0 \\
\hline
\end{tabular}

Table S2. Ireland fleet distribution in 2006, 20072013 (Ireland EPA, 2015). 